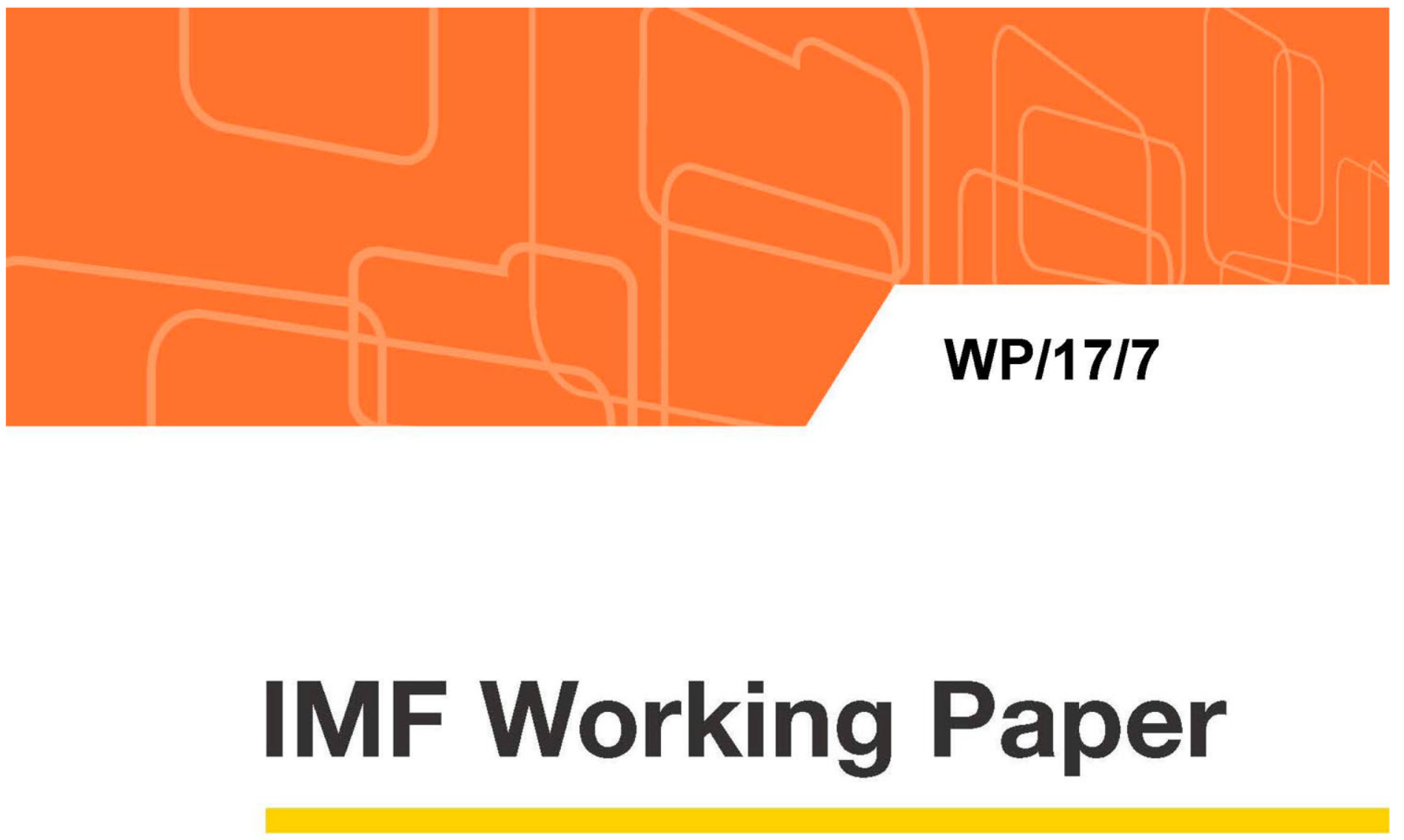

\title{
Indian Financial Sector: Structure, Trends and Turns
}

by Rakesh Mohan and Partha Ray

IMF Working Papers describe research in progress by the author(s) and are published to elicit comments and to encourage debate. The views expressed in IMF Working Papers are those of the author(s) and do not necessarily represent the views of the IMF, its Executive Board, or IMF management. 


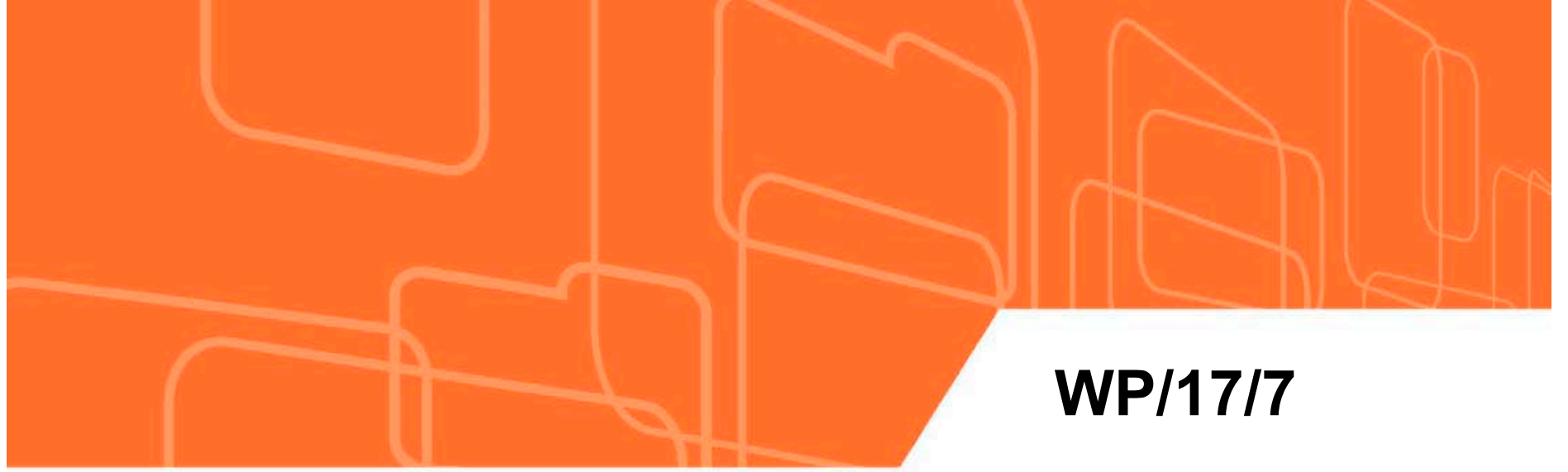

\section{IMF Working Paper}

\section{Indian Financial Sector: Structure, Trends and Turns}

by Rakesh Mohan and Partha Ray

IMF Working Papers describe research in progress by the author(s) and are published to elicit comments and to encourage debate. The views expressed in IMF Working Papers are those of the author(s) and do not necessarily represent the views of the IMF, its Executive Board, or IMF management. 


\title{
IMF Working Paper
}

Asia and Pacific Department

\section{Indian Financial Sector: Structure, Trends and Turns ${ }^{1}$}

\section{Prepared by Rakesh Mohan² and Partha Ray}

\author{
Authorized for distribution by Paul Cashin
}

January 2017

\section{IMF Working Papers describe research in progress by the author(s) and are published to elicit comments and to encourage debate. The views expressed in IMF Working Papers are those of the author(s) and do not necessarily represent the views of the IMF, its Executive Board, or IMF management.}

\begin{abstract}
This paper traces the story of Indian financial sector over the period 1950-2015. In identifying the trends and turns of Indian financial sector, the paper adopts a three period classification viz., (a) the 1950s and 1960s, which exhibited some elements of instability associated with laissez faire but underdeveloped banking; (b) the 1970s and 1980s that experienced the process of financial development across the country under government auspices, accompanied by a degree of financial repression; and (c) the period since the 1990s till date, that has been characterized by gradual and calibrated financial deepening and liberalization. Focusing more the third period, the paper argues that as a consequence of successive reforms over the past 25 years, there has been significant progress in making interest and exchange rates largely market determined, though the exchange rate regime remains one of managed float, and some interest rates remain administered. Considerable competition has been introduced in the banking sector through new private sector banks, but public sector banks continue have a dominant share in the market. Contractual savings systems have been improved, but pension funds in India are still in their infancy. Similarly, despite the introduction of new private sector insurance companies coverage of insurance can expand much further, which would also provide greater depth to the financial markets. The extent of development along all the segments of the financial market has not been uniform. While the equity market is quite developed, activities in the private debt market are predominantly confined to private placement form and continue to be limited to the bluechip companies. Going forward, the future areas for development in the Indian financial sector would include further reduction of public ownership in banks and insurance companies, expansion of the contractual savings system through more rapid expansion of the insurance and pension systems, greater
\end{abstract}

\footnotetext{
${ }^{1}$ We are grateful to participants of the 2016 Stanford India Conference for comments on some issues raised in the paper. We are also indebted to comments from the Asia Pacific Department of the Fund. We alone are responsible for any errors that remain.

${ }^{2}$ Rakesh Mohan is currently Senior Fellow at the Jackson Institute for Global Affairs, Yale University, and Distinguished Fellow, Brookings India; he was IMF Executive Director (for India, Bangladesh, Bhutan and Sri Lanka) during 2012-2015.

${ }^{3}$ Partha Ray is currently Professor of Economics at the Indian Institute of Management Calcutta, India; he was Adviser to the IMF Executive Director (for India, Bangladesh, Bhutan and Sri Lanka) during 2007-2011.
} 
spread of mutual funds, and development of institutional investors. It is only then that both the equity and debt markets will display greater breadth as well as depth, along with greater domestic liquidity. At the same time, while reforming the financial sector, the Indian authorities had to constantly keep the issues of equity and efficiency in mind.

JEL Classification Numbers: E52, E58, G21, G22, O16

Keywords: India, Financial Sector Reforms, Banks, Insurance, Pension Funds, Financial Markets.

Authors' E-Mail Addresses: rmohan1948@gmail.com; pray@iimcal.ac.in 


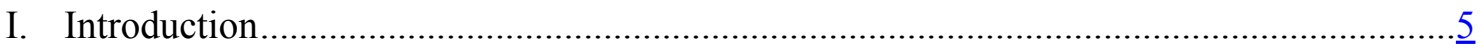

II. Indian Financial Sector: 1950-1990_From Laissez Faire to Government Control ...........

III. Banking in India since the 1990s: Towards Modern Competitive Banking ....................... $\underline{8}$

IV. The Insurance Sector Since the 1990s: Opening up the Doors.....................................19

V. Capital Market: Uneven Progress in Different Segments ..............................................

VI. External Account and India's Financial Opening …....................................................

VII. Non-Banking Finance Companies (NBFCs) — Checkered Trend ...................................

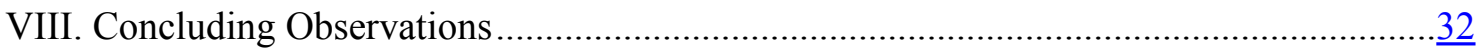

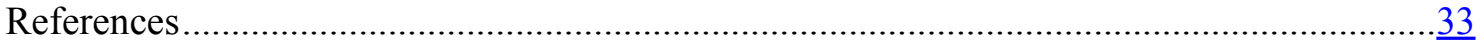

Figures

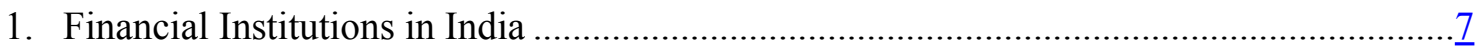

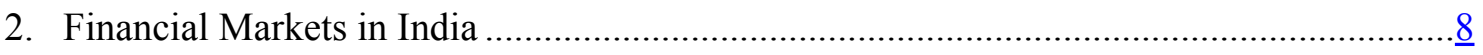

3. Liquidity Adjustment Facility (LAF) Corridor and Call Rate …................................... 10

4. Aggregate Deposit and Credit................................................................................ 11

5. Gross and Net NPAs of all Commercial Banks and Capital Adequacy Ratio.................... 13

6. Gross and Net NPAs of Different Types of Banks ...................................................15

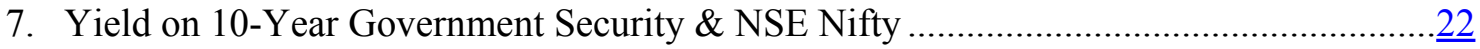

8. Market Capitalization of Wholesale Debt and Equity Markets Segments in the National

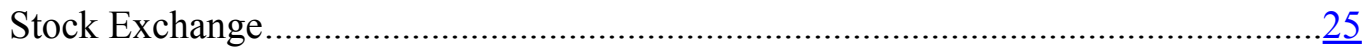

9. Average Daily Turnover in Foreign Exchange Market ...............................................28

Tables

1. Bank Rate, Cash Reserve Ratio and Statutory Liquidity Ratio ......................................

2. Select Indicators of Scheduled Commercial Banks ....................................................12

3. Operations in Different Segments in Money Market....................................................

4. Outstanding Debt of Rural Household...................................................................... 17

5. Indian Insurance Sector: Key Indicators ....................................................................

6. Resource Mobilization by the Commercial Sector in India..........................................

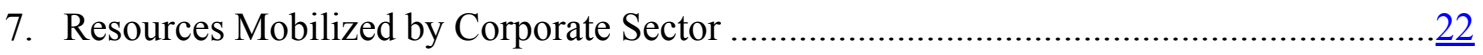

8. Turnover in Government Securities Market .............................................................

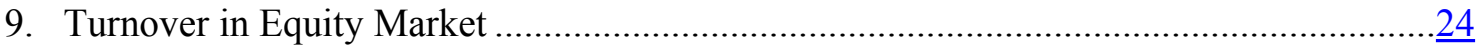

10. Net Resources Mobilized by Mutual Funds..............................................................

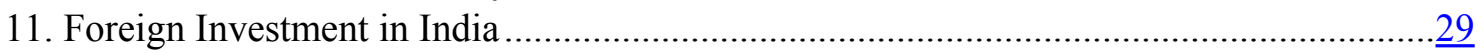

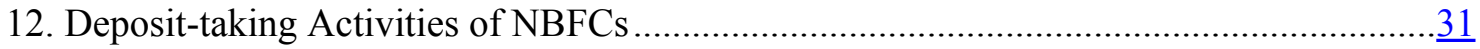




\section{Indian Financial Sector: Structure, Trends and Turns}

\section{Introduction}

The financial sector in the Indian economy has had a checkered history. The story of the post-independent (i.e., post-1947) Indian financial sector can perhaps be portrayed in terms of three distinct phases - the first phase spanning over the 1950s and 1960s exhibited some elements of instability associated with laissez faire but underdeveloped banking; the second phase covering the 1970s and 1980s began the process of financial development across the country under government auspices but which was accompanied by a degree of financial repression; and the third phase since the 1990s has been characterized by gradual and calibrated financial deepening and liberalization. While the present paper is devoted primarily to the period since the 1990s, we also provide a brief account of the earlier two phases.

\section{Indian Financial Sector: 1950-1990-From Laissez Faire to Government Control}

The Reserve Bank of India (RBI) was founded in 1935 under the Reserve Bank of India Act "...to regulate the issue of Bank Notes and keeping the reserves with a view to securing monetary stability in India and generally to operate the credit and currency system of the country to its advantage." Apart from being the central bank and monetary policy authority, the RBI is the regulator of all banking activity, including non-banking financial companies, manager of statutory reserves, debt manager of the government, and banker to the government.

At the time of independence in 1947, India had 97 scheduled $^{4}$ private banks, 557 "nonscheduled" (small) private banks organized as joint stock companies, and 395 cooperative banks. Thus, at the time of India's independence, the organized banking sector comprised three major types of players, viz., the Imperial Bank of India, joint-stock banks (which included both joint stock English and Indian banks) and the foreign owned exchange banks. The decade of 1950s and 1960s was characterized by limited access to finance of the productive sector and a large number of banking failures. ${ }^{5}$ Such dissatisfaction led the government of left-leaning Prime Minister (and then Finance Minister) Mrs Indira Gandhi to nationalize fourteen private sector banks on 20 July 1969; and later six more commercial banks in 1980. Thus, by the early 1980's the Indian banking sector was substantially nationalized, and exhibited classical symptoms of financial repression, viz., high pre-emption of banks' investible resources (with associated effects of crowding out of credit to the private sector), subject to an intricate cobweb of administered interest rates, and accompanied by quantitative ceilings on sectoral credit, as governed by the Reserve Bank of India.

Besides the commercial banks, there were four other types of financial institutions in the Indian financial sector: development finance institutions (DFIs), co-operative banks, regional rural banks and post-offices.

\footnotetext{
${ }^{4}$ The 'scheduled' banks were banks "which were included in the Second Schedule to the RBI Act and those banks in British India that subsequently became eligible for inclusion in this Schedule by virtue of their paid-up capital and reserves being more than Rs 500,000 in the aggregate...the power to include or exclude banks in or from the Schedule was vested with the Governor General in Council" (RBI, 2008)

${ }^{5}$ As against 566 commercial banks operating in 1951, only 89 survived by 1969 , the rest went into liquidation or amalgamation during 1951-1969; see RBI (2008) for details.
} 
Over the 1950s and 1960, in the absence of effective capital markets, a network of DFIs was established over much of the developing world, usually encouraged by external aid agencies. ${ }^{6}$ The sources of funds of these DFIs were diverse but raised primarily from the domestic bond market, from multilateral institutions like the World Bank, refinance window of the RBI, and government budgetary provisions. But by the 1990s, with stoppage of refinance from the RBI and government budgetary provisions, and accumulation of nonperforming assets, it became clear that the DFIs would not be viable in the long run. Consequently, the IDBI and ICICI have been converted into commercial banks, and the IFCI is effectively non-functional. NABARD, the NHB and SIDBI are continuing largely as refinance institutions with support from the government. ${ }^{7}$

As of 2015, there are 1,579 urban co-operative and 94,178 rural cooperative banks. A majority of these banks tend to operate in a single state, and they are regulated and supervised by state-specific Registrars of Cooperative Societies (RCS), along with overall oversight by the Reserve Bank of India. Thus there has been dual control of regulation and supervision of co-operative banks between the state-specific RCSs and the RBI, which has often been problematical. They have also suffered from governance problems along with the incidence of frequent local political interference which has hampered the effectiveness of these banks. There have also been slow to modernize.

Regional Rural Banks (RRBs) were established in 1975 as local level banks in different states of India. They are co-owned by the Central and State Governments, and by sponsoring public sector banks. Unlike the cooperative banks, RRBs are structured as commercial banks and were established with a view to developing the rural economy. They were envisaged to create a supplementary channel to the 'Cooperative Credit Structure' for enlarging institutional credit extended to the rural and agriculture sectors. While these were vehicles for financial inclusion, their high cost-income ratios and non-performing assets have been causes of concern. Thus, there have been substantial mergers within this sector and the number of RRBs has come down from 196 in 1990 to 56 in 2015.

The Post Office Savings Bank (POSB) has a customer base of about 330 million account holders as on March 2015 (Government of India, 2016) thereby contributing significantly to financial inclusion on the deposit side. ${ }^{8}$ However, observers of financial inclusion in India often count only bank accounts and neglect the coverage of post office accounts. The POSB offers only deposit and remittance facilities but not any credit to account holders.

The Bombay Stock Exchange, the first stock exchange in India, was founded in 1875. However, by modern standards, the Indian equity market was still quite underdeveloped till about the late 1980s. It was governed by an archaic regulatory structure whereby the Controller of Capital Issues (CCI) in the Finance Ministry was the effective equity market regulator. Government bonds were available on tap at a fixed coupon and primarily catered to

\footnotetext{
${ }^{6}$ World Bank (1989) noted, "Development finance institutions have been perhaps the most common means of directing credit. They were actively encouraged and supported by bilateral and multilateral creditors. Virtually all developing and high-income countries have at least one, and many have a special institution for each priority sector" (p. 57).

${ }^{7}$ IDBI: Industrial Development Bank of India; ICICI: Industrial Credit and Investment Corporation of India; IFCI: Industrial Finance Corporation if India; NABARD: National Bank fir Agriculture and Rural Development; NHB: National Housing Bank; SIDBI: Small Industries Development Bank of India.

${ }^{8}$ Recently the Indian postal department has been given license to open a payments bank.
} 
deficit financing of the government. Draconian foreign exchange controls resulted in a virtually non-existent market for foreign exchange.

In a similar track, insurance in India has had a long history. The life insurance business was nationalized in 1956 giving birth to the Life Insurance Corporation of India (LIC), which then had had a monopoly in the insurance business till the late 1990s when the Insurance sector was opened to the private sector. ${ }^{9}$ The general insurance business was nationalized later in 1972 when 107 insurers were amalgamated and grouped into just four government owned companies.

Thus, by the end of the 1980s, the financial sector in India was virtually owned by the government with nationalized banks and insurance companies and a single public sector mutual fund. Consequently, reforming the financial sector was a very important part of Indian economic reforms initiated in the early 1990s. Thus, over the years, the Indian financial sector has emerged as a substantial segment of the economy comprising diverse financial institutions and various markets (Figures 1 and 2).

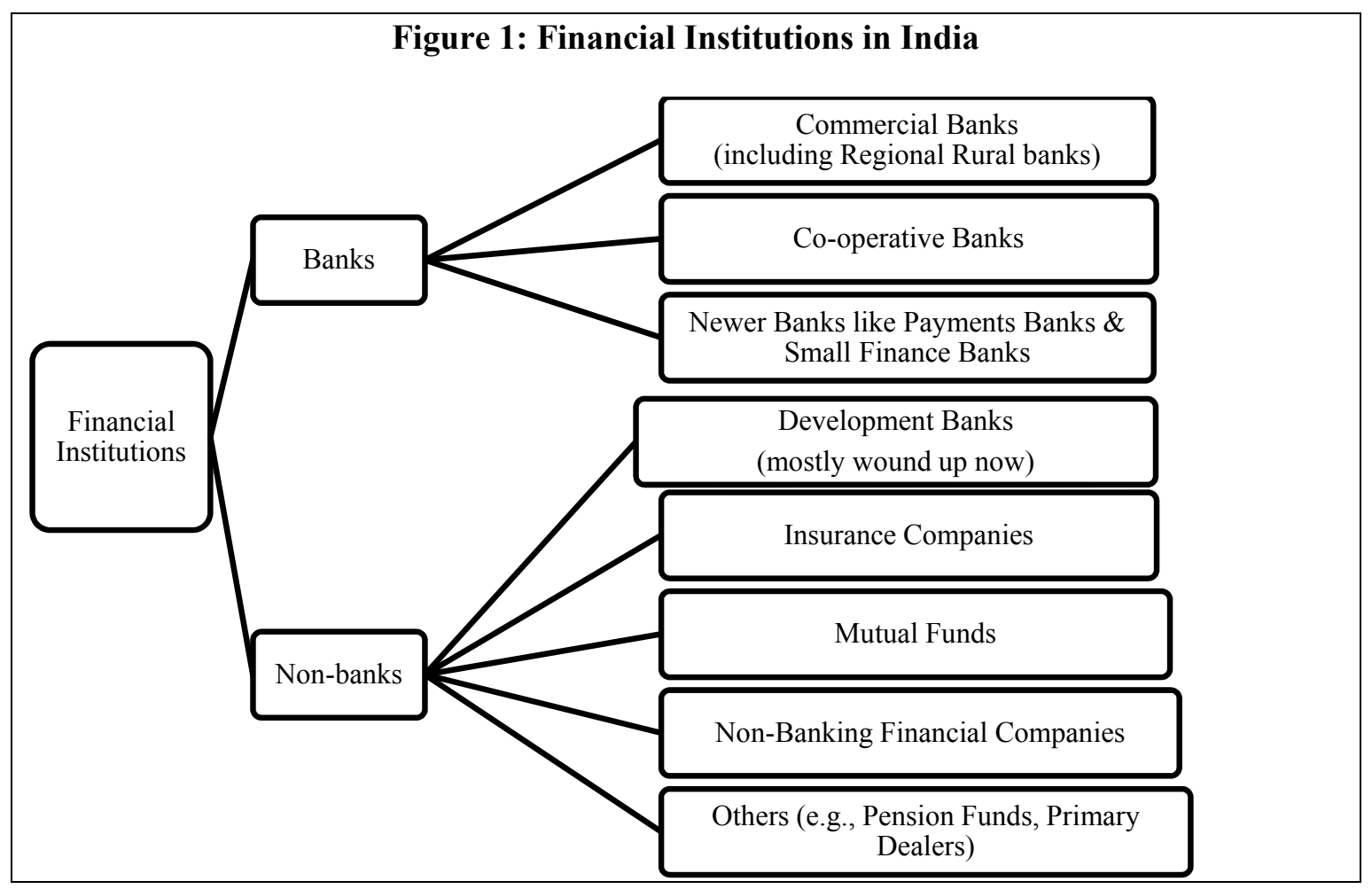

\footnotetext{
9 The LIC absorbed 154 Indian, 16 non-Indian insurers as also 75 provident societies - 245 Indian and foreign insurers in all; see IRDA (2007) for details.
} 


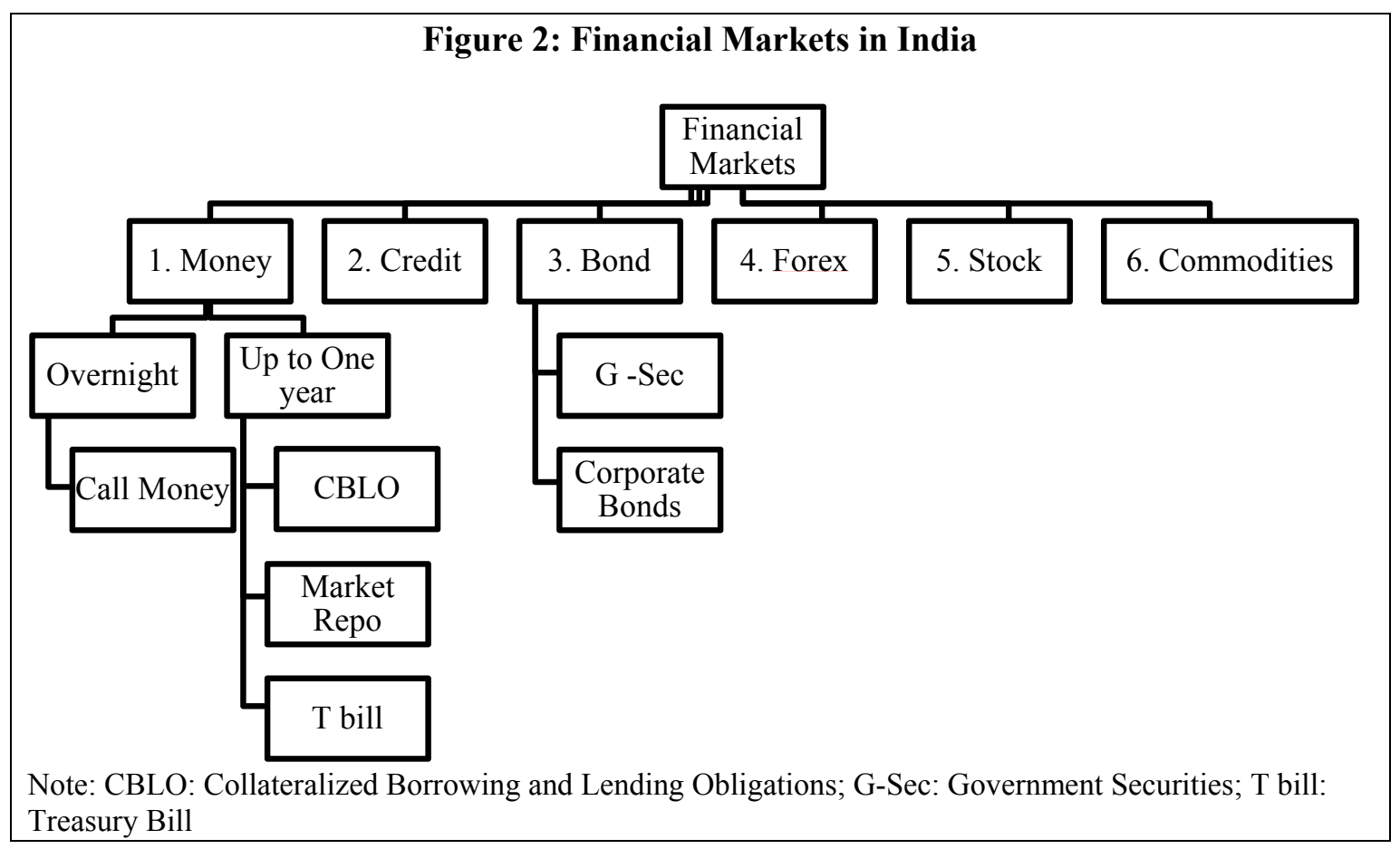

The rest of this paper is devoted to the Indian financial sector reforms and their evolution from the 1990s through mid-2010s. Sections III, IV, V and VI are devoted to the four broad genres of financial institutions viz., banking, insurance, capital market, and, India's external sector and opening up of the financial sector, respectively. Section VII takes the nonbanking financial companies in India. Section VII concludes.

\section{Banking in India since the 1990s: Towards Modern Competitive Banking}

The initial foundation of the banking sector reforms in India came from two official reports, viz., the Report of the Committee on Financial System (Reserve Bank of India, 1991) and the Report of the Committee on Banking Sector Reforms (Government of India, 1998), both chaired by former Governor of the RBI, M Narasimham. The Narasimham Committee 1991 was primarily devoted to enhancing operational freedom in the commercial banking sector and recommended measures like reduction of pre-emption of banks' investible resources (via a reduction of cash reserve ratio (CRR) and statutory liquidity ratio (SLR)) and gradual elimination of the administered interest rate structure. Narasimham Committee 1998 recommended further measures for modernising the banking sector through better regulation and supervision, and introduction of prudential norms. It also suggested a review of the bank ownership structure in India.

Other elements of financial sector reforms in India include significant reduction of financial repression (including removal of automatic monetization); dismantling of the complex administered interest rate structure to enable the process of price discovery; providing operational and functional autonomy to public sector institutions; preparing the financial system for increasing international competition; opening the external sector in a calibrated manner; and promoting financial stability in the wake of domestic and external shocks (Mohan, 2006). All these measures were designed to create an efficient, productive and profitable financial sector. Illustratively, gradual reduction of CRR from 15 percent to 
about 4 percent, and reduction in the $\mathrm{SLR}^{10}$ from nearly 40 percent to 21.5 percent between the early 1990s and the mid-2010s have made a huge improvement to the availability of lendable resources to the banking sector (Table 1). ${ }^{11}$

\begin{tabular}{|c|c|c|c|c|c|c|c|c|c|c|c|}
\hline \multicolumn{12}{|c|}{ Table 1: Bank Rate, Cash Reserve Ratio and Statutory Liquidity Ratio } \\
\hline $\begin{array}{l}\text { Effective } \\
\text { Date }\end{array}$ & $\begin{array}{r}\text { Bank } \\
\text { Rate } \\
\%\end{array}$ & $\begin{array}{r}\text { Cash } \\
\text { Reserve } \\
\text { Ratio }\end{array}$ & $\begin{array}{r}\text { Statutory } \\
\text { Liquidity } \\
\text { Ratio }\end{array}$ & $\begin{array}{r}\text { Effective } \\
\text { Date }\end{array}$ & $\begin{array}{r}\text { Bank } \\
\text { Rate } \\
\%\end{array}$ & $\begin{array}{r}\text { Cash } \\
\text { Reserve } \\
\text { Ratio }\end{array}$ & $\begin{array}{r}\text { Statutory } \\
\text { Liquidity } \\
\text { Ratio }\end{array}$ & $\begin{array}{r}\text { Effective } \\
\text { Date }\end{array}$ & $\begin{array}{r}\text { Bank } \\
\text { Rate } \\
\%\end{array}$ & $\begin{array}{r}\text { Cash } \\
\text { Reserve } \\
\text { Ratio }\end{array}$ & $\begin{array}{r}\text { Statutory } \\
\text { Liquidity } \\
\text { Ratio }\end{array}$ \\
\hline (1) & $(2)$ & (3) & (4) & (1a) & (2a) & (3a) & (4a) & (1b) & (2b) & (3b) & (4b) \\
\hline 04-07-1991 & 11.00 & 15.00 & 38.50 & 02-03-1999 & 8.00 & - & 25.00 & $19-07-2008$ & 6.00 & 8.75 & 25.00 \\
\hline 09-10-1991 & 12.00 & - & - & 13-03-1999 & - & 10.50 & - & $30-08-2008$ & - & 9.00 & - \\
\hline 09-01-1993 & - & - & 38.25 & 08-05-1999 & - & 10.00 & - & 11-10-2008 & - & 6.50 & - \\
\hline $06-02-1993$ & - & - & 38.00 & 06-11-1999 & - & 9.50 & - & $25-10-2008$ & - & 6.00 & - \\
\hline 06-03-1993 & - & - & 37.75 & 20-11-1999 & - & 9.00 & - & 08-11-2008 & - & 5.50 & 24.00 \\
\hline 17-04-1993 & - & 14.50 & - & $02-04-2000$ & 7.00 & - & - & $08-12-2008$ & - & - & - \\
\hline 15-05-1993 & - & 14.00 & - & 08-04-2000 & - & 8.50 & - & 05-01-2009 & - & - & - \\
\hline $21-08-1993$ & - & - & 37.50 & $22-04-2000$ & - & 8.00 & - & $17-01-2009$ & - & 5.00 & - \\
\hline 18-09-1993 & - & - & 37.25 & $22-07-2000$ & 8.00 & - & - & $07-11-2009$ & - & - & 25.00 \\
\hline 16-10-1993 & - & - & 34.75 & $29-07-2000$ & - & 8.25 & - & $13-02-2010$ & - & 5.50 & - \\
\hline 11-06-1994 & - & 14.50 & - & $12-08-2000$ & - & 8.50 & - & $27-02-2010$ & - & 5.75 & - \\
\hline 09-07-1994 & - & 14.75 & - & $17-02-2001$ & 7.50 & - & - & $24-04-2010$ & - & 6.00 & - \\
\hline 06-08-1994 & - & 15.00 & - & $24-02-2001$ & - & 8.25 & - & $18-12-2010$ & - & - & 24.00 \\
\hline 20-08-1994 & - & - & 34.25 & 02-03-2001 & 7.00 & - & - & $28-01-2012$ & - & 5.50 & - \\
\hline 17-09-1994 & - & - & 33.75 & 10-03-2001 & - & 8.00 & - & $13-02-2012$ & 9.50 & - & - \\
\hline 29-10-1994 & - & - & 31.50 & 19-05-2001 & - & 7.50 & - & $10-03-2012$ & - & 4.75 & - \\
\hline $11-11-1995$ & - & 14.50 & - & $23-10-2001$ & 6.50 & - & - & $17-04-2012$ & 9.00 & - & - \\
\hline $09-12-1995$ & - & 14.00 & - & 03-11-2001 & - & 5.75 & - & $11-08-2012$ & - & - & 23.00 \\
\hline 27-04-1996 & - & 13.50 & - & $29-12-2001$ & - & 5.50 & - & $22-09-2012$ & - & 4.50 & - \\
\hline 11-05-1996 & - & 13.00 & - & 01-06-2002 & - & 5.00 & - & 03-11-2012 & - & 4.25 & - \\
\hline 06-07-1996 & - & 12.00 & - & $29-10-2002$ & 6.25 & - & - & 29-01-2013 & 8.75 & - & - \\
\hline $26-10-1996$ & - & 11.50 & - & 16-11-2002 & - & 4.75 & - & 09-02-2013 & - & 4.00 & - \\
\hline 09-11-1996 & - & 11.00 & - & 29-04-2003 & 6.00 & - & - & 19-03-2013 & 8.50 & - & - \\
\hline 04-01-1997 & - & 10.50 & - & 14-06-2003 & - & 4.50 & - & 03-05-2013 & 8.25 & - & - \\
\hline 18-01-1997 & - & 10.00 & - & 18-09-2004 & - & 4.75 & - & $15-07-2013$ & 10.25 & - & - \\
\hline 16-04-1997 & 11.00 & - & - & $02-10-2004$ & - & 5.00 & - & $20-09-2013$ & 9.50 & - & - \\
\hline 26-06-1997 & 10.00 & - & - & 23-12-2006 & - & 5.25 & - & 07-10-2013 & 9.00 & - & - \\
\hline $22-10-1997$ & 9.00 & - & - & 06-01-2007 & - & 5.50 & - & $29-10-2013$ & 8.75 & - & - \\
\hline $25-10-1997$ & - & 9.75 & 25.00 & 31-01-2007 & - & - & - & $28-01-2014$ & 9.00 & - & - \\
\hline 22-11-1997 & - & 9.50 & - & $17-02-2007$ & - & 5.75 & - & 14-06-2014 & - & - & 22.50 \\
\hline 06-12-1997 & - & 10.00 & - & 03-03-2007 & - & 6.00 & - & 09-08-2014 & - & - & 22.00 \\
\hline 17-01-1998 & 11.00 & 10.50 & - & 31-03-2007 & - & - & - & $15-01-2015$ & 8.75 & - & - \\
\hline 19-03-1998 & 10.50 & - & - & 14-04-2007 & - & 6.25 & - & $07-02-2015$ & - & - & 21.50 \\
\hline 28-03-1998 & - & 10.25 & - & 28-04-2007 & - & 6.50 & - & 04-03-2015 & 8.50 & - & - \\
\hline 03-04-1998 & 10.00 & - & - & 04-08-2007 & - & 7.00 & - & 02-06-2015 & 8.25 & - & - \\
\hline 11-04-1998 & - & 10.00 & - & 10-11-2007 & - & 7.50 & - & $27-06-2015$ & - & 4.00 & - \\
\hline 29-04-1998 & 9.00 & - & - & 26-04-2008 & - & 7.75 & - & 29-09-2015 & 7.75 & - & - \\
\hline 29-08-1998 & 9.00 & 11.00 & 25.00 & $10-05-2008$ & - & 8.00 & - & 02-04-2016 & - & - & 21.25 \\
\hline & & & & 24-05-2008 & - & 8.25 & - & 05-04-2016 & 7.00 & - & - \\
\hline & & & & 05-07-2008 & 6.00 & 8.50 & 25.00 & & & & \\
\hline
\end{tabular}

With the initiation of reforms and the transition to indirect, market-based instruments of monetary policy in the 1990s, the RBI made conscious efforts to develop an efficient,

${ }^{10}$ The proportion of aggregate deposits that a bank has to keep in government and other approved securities.

${ }^{11}$ All percentages are with respect to net demand and time liabilities of commercial banks. 
stable and liquid money market by creating a favorable policy environment through appropriate institutional changes, instruments, technologies and market practices.

Accordingly, the call money market was developed into primarily an inter-bank market. Presently the Indian monetary policy framework, "aims at setting the policy (repo) rate... (where) repo rate changes transmit through the money market to alter the interest rates in the financial system". ${ }^{12}$ Once the repo rate is announced, the operating framework envisages liquidity management on a day-to-day basis through appropriate actions, which aim at anchoring the operating target - the weighted average call rate (WACR) - around the repo rate. Over the years, depending on the demand management imperatives, the RBI has used repo rate as an instrument of effective control of overnight liquidity (Figure 3 ).

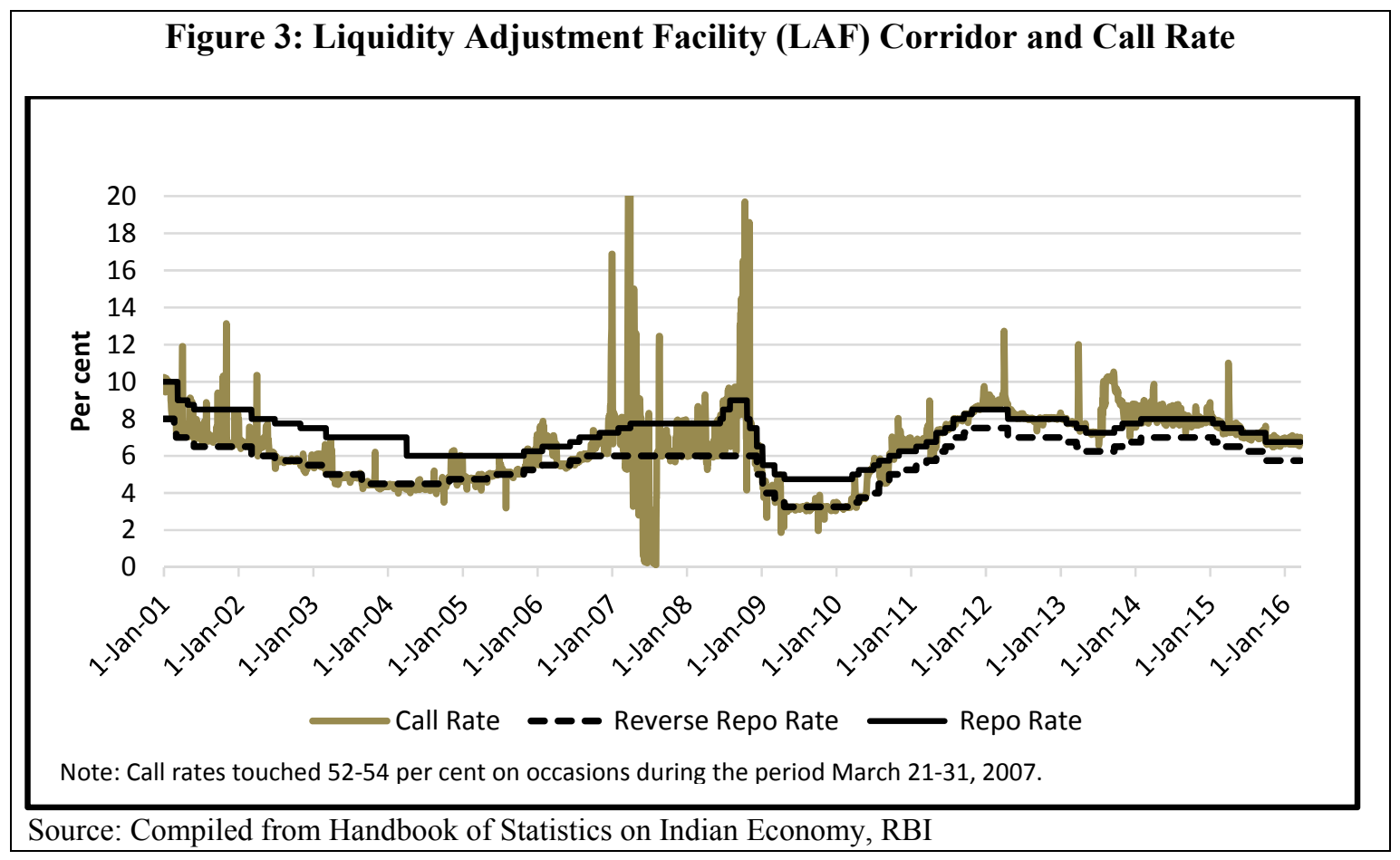

A bunch of new private sector commercial banks were licensed in the mid-1990s, the first time since bank nationalisation, in order to introduce competition, enhance efficiency and induce innovation in the banking sector.

More recently a number of measures have been initiated towards inculcating a credit culture through enforcement of creditors' rights, and hastening the process of credit recovery. The Securitization and Reconstruction of Financial Assets and Enforcement of Securities Interest (SARFAESI) Act was passed in 2002, enabling the setting up of debt-recovery tribunals and asset-reconstruction companies. Credit Information Bureaus have been given legal status through passing of the Credit Information Bureau Act in 2005, but these agencies are still in their infancy. Introduction of unique identification for every natural person in the country should potentially be very helpful for the expansion in coverage of these bureaus,

${ }^{12}$ Repo rate is the fixed interest rate at which the RBI provides short-term (overnight) liquidity to banks against the collateral of government and other approved securities under the liquidity adjustment facility (LAF)); see RBI website, https://www.rbi.org.in/scripts/FS_Overview.aspx?fn=2752 (accessed in August 2016) 
thereby leading to reduction in transactions costs for small order lending. Most recently, the Bankruptcy Act was passed by the Indian parliament in May 2016.

Information technology has played a key role in this transformative journey of Indian banking. Technology has enabled more effective, lower cost and real-time delivery of financial services, through the establishment of a modern payments system. Setting up of the Indian Financial Network (INFINET) as the communication backbone for the financial sector, introduction of a Real Time Gross Settlement System (RTGS) and core banking solutions across banks encompassing most of their branches across India, are some of the major technological initiatives implemented. Establishment of the Institute for Development and Research in Banking Technology (IDRBT) by the Reserve Bank in 1996 has helped greatly in promoting connectivity among all the banks through development of and propagation of common IT standards throughout the system. The new private sector banks, with no legacy issues to constrain them, enthusiastically adopted the new information technology from their inception, thereby also acting as a competitive spur to induce similar adoption by public sector banks.

\section{Select Outcomes}

Over the years there has been a huge increase in the extent of financialization of the Indian economy. This is reflected in upward trend in aggregate deposit and credit as a percentage of GDP (Figure 4). Post 1990s, all the reform measures led to the emergence of a modern banking sector in India and resulted in improvement in many of the profitability, efficiency and stability indicators of commercial banking in India (Table 2). The new private sector banks, along with the housing finance company HDFC, ushered in the era of retail lending and housing finance in India, starting in the late 1990s (Ahluwalia, 1999). Public sector banks followed suit with a lag. This change helped greatly in increasing the demand for automobiles, two wheelers and other consumer durables, and promoted overall economic growth in the country, while also helping in diversifying the asset base of banks.

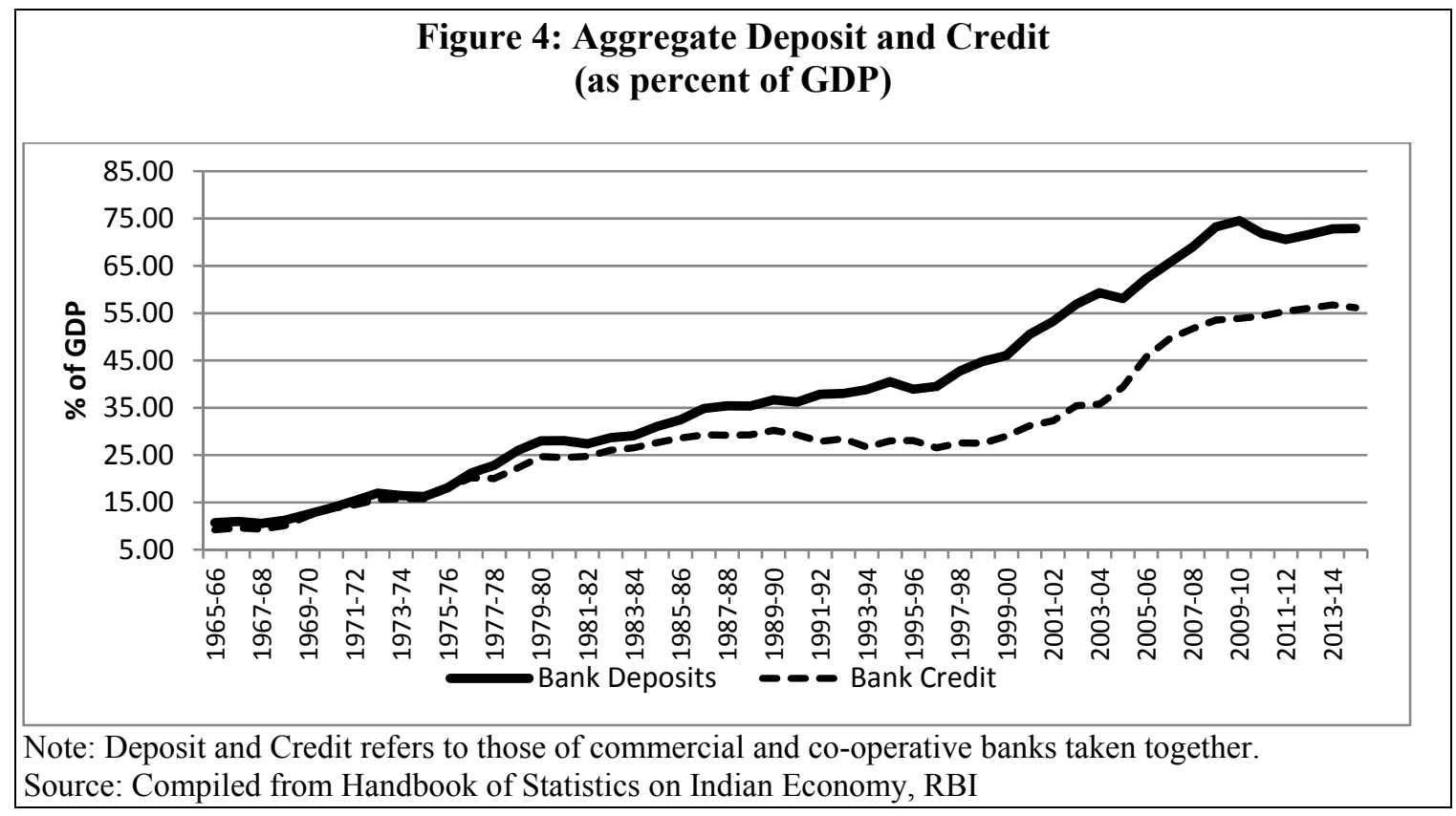




\begin{tabular}{|c|c|c|c|c|c|}
\hline \multicolumn{6}{|c|}{ Table 2: Select Indicators of Scheduled Commercial Banks (excluding Regional Rural Banks) } \\
\hline Year & $\begin{array}{r}\text { March } \\
1980 \\
\end{array}$ & $\begin{array}{r}\text { March } \\
1990\end{array}$ & $\begin{array}{r}\text { March } \\
2000\end{array}$ & $\begin{array}{r}\text { March } \\
2010\end{array}$ & $\begin{array}{r}\text { March } \\
2015\end{array}$ \\
\hline No. Of Banks & 75 & 75 & 101 & 85 & 91 \\
\hline Credit - Deposit Ratio (\%) & 63.32 & 61.64 & 49.26 & 73.66 & 78.31 \\
\hline Investment-Deposit Ratio (\%) & 31.50 & 33.58 & 45.97 & 36.42 & 33.59 \\
\hline (Credit + Investment) - Deposit Ratio (\%) & 94.82 & 95.22 & 95.23 & 110.09 & 111.90 \\
\hline $\begin{array}{l}\text { Ratio Of Deposits To Total Liabilities } \\
(\%)\end{array}$ & 73.78 & 70.60 & 81.08 & 78.76 & 78.40 \\
\hline $\begin{array}{l}\text { Ratio Of Net Interest Margin To Total } \\
\text { Assets }(\%)\end{array}$ & NA & 3.48 & 5.24 & 2.54 & 2.64 \\
\hline $\begin{array}{l}\text { Ratio Of Intermediation Cost To Total } \\
\text { Assets }(\%)\end{array}$ & NA & 4.61 & 4.79 & 1.78 & 1.77 \\
\hline $\begin{array}{l}\text { Ratio Of Wage Bills To Intermediation } \\
\text { Cost }(\%)\end{array}$ & NA & 65.68 & 66.96 & 55.23 & 54.26 \\
\hline $\begin{array}{l}\text { Ratio Of Wage Bills To Total Expense } \\
(\%)\end{array}$ & NA & 19.77 & 19.06 & 14.85 & 13.13 \\
\hline $\begin{array}{l}\text { Ratio Of Operating Profits To Total } \\
\text { Assets (\%) }\end{array}$ & NA & 0.39 & 3.21 & 2.17 & 2.02 \\
\hline Return On Assets (\%) & NA & 0.39 & 1.28 & 1.05 & 0.81 \\
\hline Return On Equity (\%) & NA & 23.37 & 22.58 & 14.31 & 10.42 \\
\hline
\end{tabular}

While experiencing strong balance sheet growth of the banks, commensurate with the impressive growth of the liberalizing Indian economy, the financial health of banks also improved significantly, in terms of both capital adequacy and asset quality (Mohan, 2011a). Illustratively, gross non-performing loans as a percentage of gross advances came down steadily from 15.7 percent in 1996 to 2.4 percent in 2009 (Figure 5). Notwithstanding recent stress, the capital to risk-weighted assets ratio of scheduled commercial banks in India was 12.7 percent while Tier-I leverage ratio stood at 6.5 percent in September 2015. ${ }^{13}$ These are impressive by standards of comparator economies. While improved capitalisation of public sector banks was initially brought through infusion of funds by government to recapitalise these banks, subsequently, public sector banks were allowed to raise funds from the market through equity issuance subject to the maintenance of 51 percent public ownership (Mohan, 2005). Along with divestiture in the public sector banks, and their subsequent listing in stock exchanges, a significant number of private sector banks were allowed entry; consequently, the share of public sector banks continued to decline gradually in banking business and a private sector bank emerged as the second largest bank in India over the last ten years or so. In terms of adoption of technology, the share of electronic payments has been increasing continuously.

\footnotetext{
${ }^{13}$ Tier-I leverage ratio is defined as the ratio of Tier-I capital to total assets; total assets include the credit equivalent of off-balance sheet items.
} 


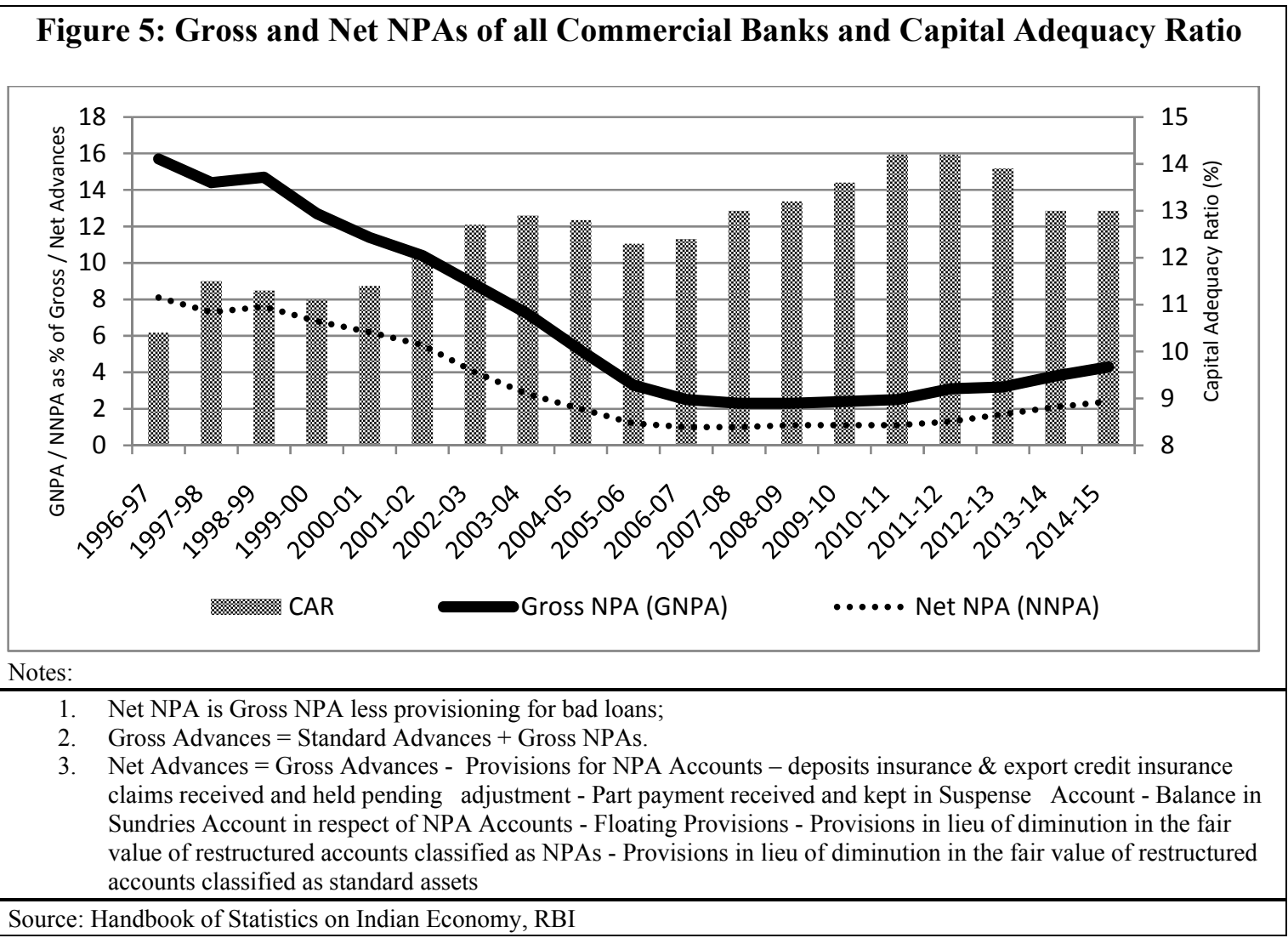

\section{Money Market}

The money market is a key component of the banking sector and monetary policy in India. With a ceiling on the over-night interbank money market (known as call money market), the status of the money market was quite archaic in India until the early 1990s. With the initiation of financial sector reforms and the need to make monetary policy operational the call money market had to be developed gradually into an inter-bank market through which monetary policy transmission takes place. RBI's policy rate is effectively the repo rate now, which acts as the anchor of the money market through operation of its liquidity adjustment facility (LAF). The mode of operation of the call money market and its efficiency is crucial for effectiveness of transmission of RBI's monetary policy. Hence the framework of the LAF has undergone various tweaks over time as monetary conditions and operational frameworks have changed. Over the years, the money market has become deep and diverse with emergence of several segments like CBLO (collateralized borrowing and lending obligations); it experienced significant increase in the level of activity in its various segments (Table 3 ).

An important institutional reform was the establishment of the Clearing Corporation of India Limited (CCIL) as a central counterparty to provide guaranteed clearing and settlement functions for transactions in money, G-Secs, foreign exchange and derivative markets. This led to significant improvement in the market efficiency, transparency, liquidity and risk management/measurement practices in these markets along with added benefits like reduced settlement and operational risk, savings on settlement costs. CCIL also provides nonguaranteed settlement for Rupee interest rate derivatives and cross currency transactions through the CLS Bank. Further, new innovative instruments, such as collateralized borrowing and lending obligations (CBLO; a tripartite repo between any two financial entities along with 
CCIL) and market repo were introduced for widening and deepening the money market. These instruments provided avenues for non-banks to manage their short-term liquidity mismatches and facilitated the transformation of the call money market into a pure inter-bank market (Mohan, 2005). Furthermore, issuance norms and maturity profiles of instruments such as commercial paper (CP) and certificate of deposits (CDs) have been modified over time to encourage wider participation.

\begin{tabular}{|c|c|c|c|c|c|c|c|c|c|c|}
\hline \multicolumn{11}{|c|}{$\begin{array}{l}\text { Table 3: Operations in different segments in Money Market: Average Daily Turnover } \\
\text { (Rs. billion) }\end{array}$} \\
\hline & \multicolumn{4}{|c|}{ Overnight Segment } & \multicolumn{4}{|c|}{ Term Segment } & \multicolumn{2}{|c|}{$\begin{array}{c}\text { Liquidity } \\
\text { Adjustment Facility }\end{array}$} \\
\hline \multirow{2}{*}{ Date } & \multirow{2}{*}{ Call } & \multirow{2}{*}{ CBLO } & \multirow{2}{*}{$\begin{array}{r}\text { Market } \\
\text { Repo }\end{array}$} & \multirow{2}{*}{$\begin{array}{r}\text { Overnigh } \\
\text { t Total }\end{array}$} & \multirow{2}{*}{$\begin{array}{l}\text { Notice } \\
\text { Money }\end{array}$} & \multirow{2}{*}{$\begin{array}{r}\text { Term } \\
\text { Money }\end{array}$} & \multirow{2}{*}{ CBLO } & \multirow{2}{*}{$\begin{array}{r}\text { Market } \\
\text { Repo }\end{array}$} & \multirow{2}{*}{$\begin{array}{r}\text { Repo } \\
\text { (Fixed } \\
\text { Rate) }\end{array}$} & $\begin{array}{r}\text { Reverse } \\
\text { Repo }\end{array}$ \\
\hline & & & & & & & & & & $\begin{array}{r}\text { (Fixed } \\
\text { Rate) }\end{array}$ \\
\hline $2000-01$ & 322 & - & 105 & 427 & & & & & & \\
\hline 2001-02 & 351 & - & 302 & 653 & & & & & & \\
\hline $2002-03$ & 294 & - & 470 & 764 & & & & & & \\
\hline 2003-04 & 172 & 5 & 104 & 281 & & & & & & \\
\hline $2004-05$ & 142 & 67 & 171 & 380 & & & & & & \\
\hline $2005-06$ & 180 & 200 & 212 & 592 & 46 & 6 & - & 104 & & \\
\hline 2006-07 & 217 & 324 & 337 & 878 & 47 & 6 & - & 104 & & \\
\hline $2007-08$ & 214 & 556 & 547 & 1317 & 28 & 4 & - & 231 & & \\
\hline 2008-09 & 224 & 616 & 573 & 1413 & 77 & 6 & - & 267 & 432 & 570 \\
\hline $2009-10$ & 159 & 1091 & 854 & 2104 & 45 & 4 & - & 375 & 13 & 2054 \\
\hline 2011-12 & 217 & 773 & 450 & 1441 & 63 & 6 & - & 229 & 1642 & 65 \\
\hline $2012-13$ & 250 & 832 & 748 & 1831 & 74 & 11 & - & 297 & 1709 & 23 \\
\hline 2013-14 & 231 & 1196 & 953 & 2380 & 73 & 6 & - & 500 & 1644 & 63 \\
\hline 2014-15 & 190 & 1146 & 1120 & 2456 & 69 & 5 & 256 & 551 & 281 & 137 \\
\hline $2015-16$ & 224 & 1159 & 1257 & 2640 & 52 & 6 & 321 & 610 & 247 & 248 \\
\hline
\end{tabular}

\section{Emerging Issues}

Notwithstanding such trends, the Indian banking sector continued to remain predominantly public in nature, with the public sector banks still accounting for more than 70 percent of total banking sector assets. A recent official report argued for reduction in government shareholding to below 50 percent to allow more autonomy to banks as well as to create distance between the government and governance of banks (RBI, 2014). However, during 2014-15, despite their substantive share in total assets, public sector banks accounted for only 42 percent in total profits (RBI, 2015), down from 74 percent in 2003-04. Are the public sector banks inherently less efficient than the private banks? Or, is their less impressive performance an outcome of an inefficient governance structure subject to bureaucratic interference? Do Indian banks continue to suffer from the imperatives of societal concerns and thus, torn between the dilemmas of efficiency and equity? The fact that the performance of public sector banks had converged to that of the new private sector banks by 2008-09, before 
deteriorating subsequently poses a further puzzle, raises further questions about the determinants of their performance.

The issue of recent deterioration of asset quality in public sector banks has emerged as the key concern surrounding the banking sector today. Earlier, gross non-performing assets (GNPAs) of the Indian banking sector, as a percentage of gross advances, had come down from 15 percent in 1998 to 3.3 percent in 2009: since then GNPAs have increased steadily to 5.1 percent by the end of 2015 (Figure 6). Taking a wider definition, the stressed assets (i.e., gross NPA plus restructured standard assets plus written off accounts) for the banking system as a whole increased from 9.8 percent in 2012 to 14.5 percent in 2015; stressed assets in public sector banks increased from 11.0 percent to 17.7 percent during the same period (Mundra, 2016a, 2016b).

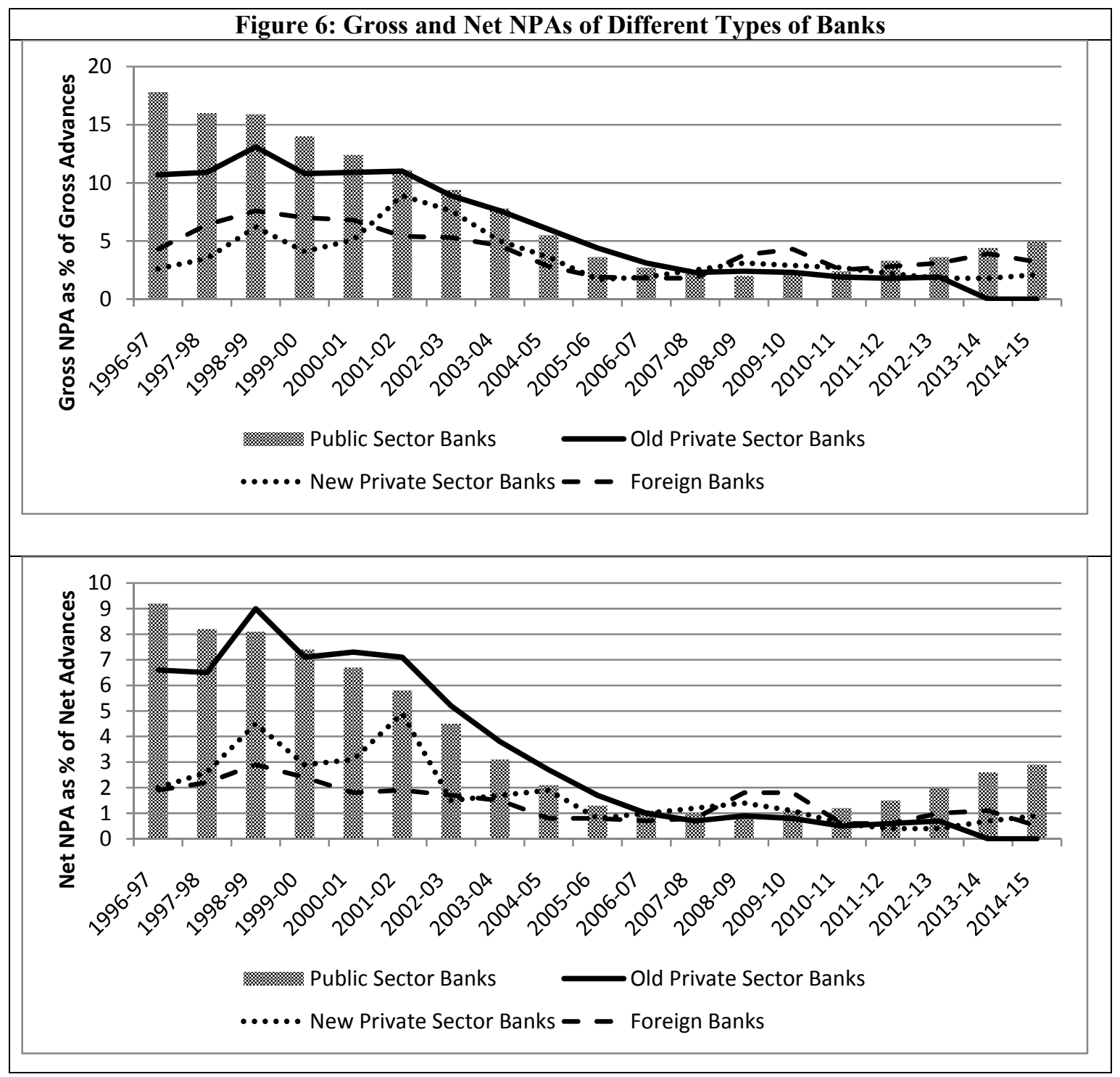

Interestingly, in recent years, small industries as well as agricultural loans do not seem to have contributed the lion's share of this formation of NPAs, as they used too in the past. It 
is the industrial sector-primarily the infrastructure and steel sectors that have experienced greater deterioration in asset quality. Thus, questions are being asked as to how such NPAs got accumulated in recent years. First, in the aftermath of the North Atlantic Financial Crisis ${ }^{14}$ the RBI relaxed credit norms in order to encourage bank lending - a phenomenon that is called "regulatory forbearance" in Central Bank Speak. ${ }^{15}$ Second, in the period following the NAFC, an array of structural factors and the sharp fall in commodity prices has led to sharp declines in the profitability of sectors such as steel; this could have caused the problem of unpaid debt to banks from these and associated sectors. Third, the government thrust on infrastructure investment through public-private-partnerships (PPP) led to huge new debt being contracted by highly leveraged Indian corporate entities investing in infrastructure. Government pressure combined with private sector enthusiasm for PPP infrastructure projects may have led banks to deviate from the rigorous discipline of credit appraisal and due diligence. Fourth, there are allegations of governance issues with the management of select public sector banks and cases of political interference. Thus, in select cases lending decisions could have got divorced from discipline of standard credit evaluation process and due diligence (Credit Suisse, 2015).

Financial inclusion has been a concern in India since at least the early part of the last century. The setting up of a postal savings bank, rural and urban co-operative banks, regional rural banks, and the nationalisation of banks, were all done at different points in time to promote financial inclusion. Despite all the decades of social sector banking and success in spreading the banking network, there has been evidence that poorer sections of the society have not been able to access financial services adequately from the organized financial system (NABARD, 2008). ${ }^{16}$

India's approach to financial inclusion has been multi-pronged. One of its major corner-stones is the presence of stipulations on "priority sector lending" by the commercial banks. For this purpose, priority sector includes the following categories, viz., agriculture; micro, small and medium enterprises; export credit; education; housing; social infrastructure; renewable energy; and others (like weaker section of the community). Indian commercial banks are required to lend 40 percent of their credit to the priority sector. ${ }^{17}$ Now Foreign

\footnotetext{
${ }^{14}$ We use the term "North Atlantic" Financial Crisis (NAFC), rather than "Global" Financial Crisis advisedly. No financial institutions had to be rescued by governments or central banks outside North America and Europe. So NAFC is a better label for this crisis, just as the Asian Financial Crisis was not seen as a Global Financial Crisis. Both financial crises did have global economic impacts.

${ }^{15}$ Three major measures were taken: (a) provisioning requirements for most of the types of standard assets was reduced to a uniform level of 0.40 per cent; (b) risk weights on banks' exposures to certain sectors were revised downward; and (c) as one-time measures and for a limited period, prudential regulations for restructured account were modified for applications received up to March 31, 2009 - the modifications permitted restructured accounts to be treated as standard assets, provided they were standard on the eve of the crisis, i.e., September 1, 2008 , even if they turned non-performing at the time of restructuring. In fact, RBI (2014a) noted, "While it may be somewhat legitimate to justify regulatory forbearance in times of major crises, forbearance for extended periods and as a cover to compensate for lenders/borrowers' inadequacies engenders moral hazard. ... Hence, an early end to regulatory forbearance may be the right step" (p. 45).

${ }^{16}$ Similar sentiments were echoed in the report of the Committee on Financial Sector Reforms (Chairman: Raghuram Rajan; Government of India, 2009), which noted: "Financial sector policies in India have long been driven by the objective of increasing financial inclusion, but the goal of universal inclusion is still a distant dream (p. 49).

17 Technically, the ambit of the target of priority sector credit is with respect to "adjusted net bank credit (ANBC) or credit equivalent amount of off-balance sheet exposure, whichever is higher". ANBC denotes the outstanding Bank Credit in India minus bills rediscounted with RBI and other approved Financial Institutions plus permitted non SLR bonds/debentures under Held to Maturity (HTM) category plus other investments eligible to be treated
}

(continued...) 
banks with 20 branches and above also have to achieve the 40 percent total within a maximum period of five years over April 2013-March 2018 as per the action plans submitted by them and approved by RBI. Besides, there are sub-targets within this overall 40 percent target; illustratively, 18 percent has to be disbursed to agriculture while 7.5 percent has to be disbursed to the small and medium enterprises. In recent times, introduction of Priority Sector Lending Certificates (PSLCs) have enabled banks to achieve the priority sector lending target and sub-targets by purchase of these instruments in the event of shortfall. Further, commercial banks can also invest the amount of their shortfalls in the Rural Infrastructure Development Fund (RIDF) run by NABARD. There are several diverse dimensions of financial inclusion such as, income, region/province, caste, gender, economic size of the firm/household, and type of economic activity. The incidence of farmers' suicides has also cast doubt about the efficacy of the formal credit delivery mechanism as well as the limitations of credit disbursals from micro-finance institutions and self-help groups. The All India Debt and Investment Survey of December 2013 indicated that during 2012-13, non-institutional sources (i.e., sources of credit other than government, banks, insurance companies, pension funds, financial companies, and so on) continued to play a major role in providing credit to the rural households - about 19 percent of all rural households have acquired credit from noninstitutional sources while for urban households about 10 percent by non-institutional agencies (Table 4).

\begin{tabular}{|c|c|c|c|c|c|c|c|}
\hline & \multicolumn{4}{|c|}{ Table 4: Outstanding Debt of Rural Household: Institutional versus Non-Institutional Sources (\%) } & & & \\
\hline Sources of Credit & 1951 & 1961 & 1971 & 1981 & 1991 & 2002 & $2012 *$ \\
\hline Non-institutional & 92.8 & 85.2 & 70.8 & 38.7 & 36.0 & 42.9 & 40.2 \\
\hline Landlords & 3.5 & 0.9 & 8.6 & 4.0 & 4.0 & 1.0 & \\
\hline Agricultural moneylenders & 25.2 & 45.9 & 23.1 & 8.6 & 7.1 & 10.0 & \\
\hline Professional moneylenders & 46.4 & 14.9 & 13.8 & 8.3 & 10.5 & 19.6 & \\
\hline Institutional & 7.2 & 14.8 & 29.2 & 61.3 & 64.0 & 57.1 & 59.8 \\
\hline \multicolumn{8}{|l|}{ of which: } \\
\hline Government & 3.7 & 5.3 & 6.7 & 4.0 & 6.1 & 2.3 & \\
\hline Co-operative societies & 3.5 & 9.1 & 20.1 & 28.6 & 21.6 & 27.3 & \\
\hline Commercial banks & n.a. & 0.4 & 2.2 & 28.0 & 33.7 & 24.5 & \\
\hline Total & 100.0 & 100.0 & 100.0 & 100.0 & 100.0 & 100.0 & 100.0 \\
\hline \multicolumn{8}{|c|}{$\begin{array}{l}\text { * There are issues relating to comparability of the constituent groups of data collected under } 59^{\text {th }} \text { round of NSS } \\
\text { (for } 2002) \text { and } 70^{\text {th }} \text { round of NSS (2012). } \\
\text { Source: Mohan }(2011 \text { b) and NSS (2012) }\end{array}$} \\
\hline
\end{tabular}

There are, of course, two ways of interpreting such trends and it is difficult to decide whether the glass is half empty or three quarters full (Mohan, 2011b). In fact, the improvement in financial inclusion in the recent past can be associated with an activist stance of the authorities in ensuring financial inclusion. Some the key measures in this regard include opening of No-Frills accounts in commercial banks; introduction of a credit card specifically for the farmers' community (Kisan Credit Card); and engaging Business Correspondents (BC)

as part of priority sector lending (e.g. investments in securitized assets); see RBI's "Master Circular - Priority Sector Lending- Targets and Classification", available at https://rbi.org.in/Scripts/BS ViewMasCirculardetails.aspx?id=9857\#C8 
as intermediaries for providing financial and banking services. A recent major initiative is the Pradhan Mantri Jan-Dhan Yojana (Prime Minister's People Money Scheme). Introduced in August 2014, this scheme has now become synonymous with a National Mission on Financial Inclusion and has envisaged universal access to banking facilities with at least one basic banking account for every household. Apart from accessing basic banking services like credit, insurance and pension facility, the beneficiaries get a Debit card having inbuilt accident insurance cover of Rs 100,000. By July 2016, over 230 million new bank accounts were opened and Rs. 400 billion was deposited under the scheme. ${ }^{18}$

There are three recent developments with regard to entry of new private sector banks. First, after nearly 10 years of no new banking licenses, licenses were granted in 2015 to two existing financial institutions to become universal commercial banks: IDFC Ltd (an integrated infrastructure finance company) and Bandhan Financial Services (a large micro finance organization). ${ }^{19}$ Two new major types of small and differentiated banks - payments banks and small finance banks - have also emerged as the newest entrants in the Indian financial sector. While payments banks are essentially narrow banks (i.e., without any lending activity) which can raise deposits of up to Rs. 100,000 and pay interest on these balances just like a savings bank account does, their basic business model is geared towards utilizing newer mobile technology and payment gateways whereby they can enable transfers and remittances through a mobile phone and can issue debit cards and ATM cards usable on ATM networks of all banks. Ever since August 2015 when the RBI issued licenses to 11 entities ${ }^{20}$ to establish payments banks, there is speculation whether this would usher in a new era of Indian banking. At the same time, small finance banks are being licensed to further financial inclusion primarily through mobilization of savings as well as supply of credit to small business units (such as, small and marginal farmers; micro and small industries; and other unorganised sector entities) through high technology-low cost operations. Small finance banks are similar to regular commercial banks except that their scale of services will be much smaller: 50 percent of their loans should be of ticket sizes under Rs. 2.5 million. Small banking licenses have been issued to 10 entities, most of which are successful micro-finance institutions. The use of new information technology is expected to propel these new banks in their efforts to enhance financial inclusion.

Many of these developments mark a departure from the past. Illustratively, unlike the past when only universal banking licences were issued, now differentiated banking licenses are also being issued. Similarly, although there has been a general policy of not issuing bank licenses to non financial big industry houses, payments banks licenses were issued to some big industry houses as well. The justification is that since payments banks are essentially narrow banks not permitted to do any lending, the possibility of conflict of interest arising from intra group lending is not an issue. Thus, going forward these small but differentiated banks could constitute competitive challenges to the existing commercial banks in terms of access to financial savings for on lending. Will there be flight of retail deposits from bigger commercial banks to these banks from the same pool of depositors, or will they be effective in enhancing overall financial savings in the system? The business model of payments banks may face some challenges since their earning opportunities will be restricted to investments in government securities.

\footnotetext{
${ }^{18}$ http://www.pmjdy.gov.in/ (accessed in August 2016)

${ }^{19}$ More recently (on May 5, 2016), deviating from past practice of stop and go licenses, the RBI released Draft Guidelines for 'on tap' Licensing of Universal Banks in the Private Sector.

20 Three of these entities have already surrendered their licenses as of July 2016.
} 
How can we summarize the story of the Indian banking sector in recent times? At the risk of oversimplification, the following trends can be highlighted. First, while commercial banks have seen an all-round improvement in key financial indicators, particularly in areas of capital adequacy, asset quality and earnings, their recent trends raise some disquieting developments. Second, "the financial results of the co-operative banking structure however, show some degree of vulnerability, though they may not be systemically very large" (RBI, 2009). Third, the new entrants in the financial sector, viz., payments banks and small savings banks are at this juncture are really unknown unknowns. Finally, while various efforts towards financial inclusion seemed to have bear fruit, there is much to achieve.

\section{The Insurance Sector Since the 1990s: Opening up the Doors}

A high-powered committee, set up in 1993 by the Government of India and headed by former RBI Governor, R. N. Malhotra, initiated the reforms process in the Indian insurance sector. Apart from opening up the insurance sector to private players-both to domestic and foreign players (preferably through joint ventures with Indian partners), the Committee recommended establishment of the Insurance Regulatory and Development Authority (IRDA) as an autonomous body to regulate, develop and promote competition in the insurance sector. The IRDA was finally constituted as an autonomous body in 1999 and incorporated as a statutory body in April 2000. The mission of IRDA is "to protect the interests of the policyholders, to regulate, promote and ensure orderly growth of the insurance industry and for matters connected therewith or incidental thereto."

With the enactment of the IRDA Act, 1999, the monopoly conferred to the Life Insurance Corporation in 1956 and to the General Insurance Corporation in 1972 was repealed, allowing private sector players to enter the insurance sector. A recent development in the insurance sector has been enhancement of the limit of foreign investment in insurance sector from 26 to 49 percent under the automatic route.

As of March 2015, this sector comprised 24 life insurance companies and 28 general insurance companies, and one national reinsurer. Among the life insurers, the Life Insurance Corporation (LIC) as the sole public sector company accounts for the lion's share in insurance business. Among the non-life insurers there are six public sector insurers. In addition to these, there is the sole national re-insurer, namely, General Insurance Corporation of India (GIC). Out of 28 non-life insurance companies, there are five private sector players dealing exclusively in health, personal accident and travel insurance segments.

With about 360 million policies, India's life insurance sector is perhaps the biggest in the world in terms of number - reflecting India's population size. The general insurance business in India is currently at Rs. 847 billion in 2014-15 or about 0.7 percent of GDP. In 2014, with a share of 2.1 percent in the global life insurance business, India has been ranked 11th among the 88 countries in life insurance business (Swiss Re, 2015). In non-life insurance while vehicle insurance accounted for nearly 40 percent of the gross direct premiums earned in 2015-16, penetration of health insurance is rather poor. In fact, despite the absolute size of the insurance sector, penetration in this sector leaves much to be desired. Illustratively, while the rate of insurance penetration in life segment (measured by the ratio of premium to GDP) of India increased from 2.2 percent to in 2002 to 4.6 percent in 2010, it declined thereafter to reach 2.6 percent in 2014 (Table 5). Industry reports tended to indicate that with higher inflation and lower disposable incomes, overall intention to buy life insurance policies in India has taken a hit (Saraswathy, 2015). Interestingly, at the current juncture while India's 
insurance penetration is comparable to China's 3.2 percent - similar metrics for Korea (at 11.3 percent) or Thailand (at 5.8 percent) are much higher (IRDA, 2015).

Although the insurance sector initially experienced robust growth (around 31 percent in new business premiums) in the decade of 2001-2010 after opening up, there has been a slowdown subsequently (KPMG, 2012). This sluggish growth brings to the fore various challenges in the Indian insurance business. Though its share in total business has indeed come down come down the insurance sector is still dominated by the public sector. Illustratively, in 2014-15 the share of LIC in total premium was around 73 percent, in case of non-life insurance business, the private and public sector companies have approximately equal share. The share of the life insurance fund as a proportion of changes in gross financial assets of the household sector have gone up significantly and tended to hover around 20 percent recent years.

\begin{tabular}{|c|c|c|c|c|c|c|c|c|}
\hline \multicolumn{9}{|c|}{ Table 5: Indian Insurance Sector: Key Indicators } \\
\hline & \multicolumn{4}{|c|}{ Life Insurance Sector } & \multicolumn{4}{|c|}{ Non-Life Insurance Sector } \\
\hline Year & $\begin{array}{r}\text { No of } \\
\text { Companies } \\
\text { (as on } \\
\text { March 31) }\end{array}$ & $\begin{array}{r}\text { No. of } \\
\text { branches } \\
\text { (as on } \\
\text { March } \\
31)\end{array}$ & $\begin{array}{r}\text { Insurance } \\
\text { Penetration } \\
(\%) \\
\text { (calendar } \\
\text { year) }\end{array}$ & $\begin{array}{r}\text { Insurance } \\
\text { density } \\
\text { (calendar } \\
\text { year) }\end{array}$ & $\begin{array}{r}\text { No of } \\
\text { Companies } \\
\text { (incl } \\
\text { reinsurer) } \\
\text { (as on } \\
\text { March 31) }\end{array}$ & $\begin{array}{r}\text { No.s of } \\
\text { branches } \\
\text { (as on } \\
\text { March } \\
31)\end{array}$ & $\begin{array}{r}\text { Insurance } \\
\text { Penetration } \\
(\%) \\
\text { (calendar } \\
\text { year) }\end{array}$ & $\begin{array}{r}\text { Insurance } \\
\text { density } \\
\text { (calendar } \\
\text { year) }\end{array}$ \\
\hline 2000-01 & 5 & 2199 & & & 10 & & & \\
\hline $2001-02$ & 12 & 2306 & 2.2 & 9.1 & 13 & & 0.5 & 2.4 \\
\hline $2002-03$ & 13 & 2445 & 2.6 & 11.7 & 15 & & 0.6 & 3.0 \\
\hline $2003-04$ & 13 & 2612 & 2.3 & 12.9 & 16 & & 0.6 & 3.5 \\
\hline $2004-05$ & 14 & 3001 & 2.5 & 15.7 & 16 & & 0.6 & 4.0 \\
\hline $2005-06$ & 15 & 3865 & 2.5 & 18.3 & 16 & & 0.6 & 4.4 \\
\hline 2006-07 & 16 & 5373 & 4.1 & 33.2 & 17 & & 0.6 & 5.2 \\
\hline $2007-08$ & 18 & 8913 & 4.0 & 40.4 & 20 & & 0.6 & 6.2 \\
\hline 2008-09 & 22 & 11815 & 4.0 & 41.2 & 22 & & 0.6 & 6.2 \\
\hline $2009-10$ & 23 & 12018 & 4.6 & 47.7 & 26 & 6417 & 0.6 & 6.7 \\
\hline $2010-11$ & 23 & 11546 & 4.4 & 55.7 & 26 & 6660 & 0.7 & 8.7 \\
\hline $2011-12$ & 24 & 11167 & 3.4 & 49.0 & 28 & 7050 & 0.7 & 10.0 \\
\hline $2012-13$ & 24 & 10285 & 3.2 & 42.7 & 28 & 8099 & 0.8 & 10.5 \\
\hline 2013-14 & 24 & 11032 & 3.1 & 41.0 & 29 & 9872 & 0.8 & 11.0 \\
\hline $2014-15$ & 24 & 11033 & 2.6 & 44.0 & 29 & 10407 & 0.7 & 11.0 \\
\hline \multicolumn{9}{|c|}{$\begin{array}{l}\text { Note: While insurance penetration is measured as the percentage of insurance premium to GDP, insurance } \\
\text { density is calculated as the ratio of premium to population (per capita premium) } \\
\text { Source: Handbook on Indian Insurance Statistics 2014-15, Insurance Regulatory and Development } \\
\text { Authority Of India }\end{array}$} \\
\hline
\end{tabular}

The current issues facing Indian insurance are diverse. The key issue is the need for much greater expansion of insurance services, particularly that of life insurance and health insurance. Apart from the need for better spread of social protection, the expansion of insurance funds is also essential for the development of capital markets, particularly the corporate debt market which is typically dependent in institutional investors. Other issues include the efficiency and spread of distributional channels, the level of government control, regulatory constraints, and consumer education and protection (IMF, 2013). Continuance of 
an archaic agent-based distribution channels has led to allegations of mis-selling of insurance products as well as low persistency of insurance policies in India (Government of India, 2015). Besides, there is a huge untapped potential in sectors like health insurance.

\section{Capital Market: Uneven Progress in Different Segments}

Is the Indian financial system bank-based or market based? While our prior hunch could characterize Indian financial system as a bank-based one, it is important to note that significant change is happening in this sphere. Table 6 in this context reports the resource mobilization by the commercial sector. Interestingly, Indian corporates' recourse to non-bank sources tended to hover between 40-50 percent during the period 2009-10 through 2015-16. Both domestic as well as foreign sources are significant in the case of non-bank funding sources. However, in terms of resource mobilization, the Indian capital market has depended heavily on private placement whose costs are found to be much lower (Table 7). As far as price discovery is concerned, the capital market reflects the operations of market forces; this is reflected in the movement of yield on 10-year benchmark government security as well as indices in equity market like NSE Nifty 50 (Figure 7).

\begin{tabular}{|c|c|c|c|c|c|c|c|c|c|}
\hline \multicolumn{10}{|c|}{$\begin{array}{r}\text { Table 6: Resource Mobilization by the C } \\
\text { (Rs. billion) }\end{array}$} \\
\hline & $\begin{array}{l}2007- \\
08\end{array}$ & $\begin{array}{l}2008- \\
09\end{array}$ & & $\begin{array}{l}2010- \\
11 \\
\end{array}$ & $\begin{array}{l}2011- \\
12 \\
\end{array}$ & $\begin{array}{l}2012- \\
13 \\
\end{array}$ & $\begin{array}{l}2013- \\
14 \\
\end{array}$ & $\begin{array}{l}2014- \\
15 \\
\end{array}$ & $\begin{array}{l}2015- \\
16 \\
\end{array}$ \\
\hline \multirow{2}{*}{ A. Adjusted Non-Food Bank Credit } & 4,448 & 4,211 & 4,786 & 7,110 & 6,773 & 6,849 & 7,627 & 5,850 & 7,754 \\
\hline & $(44.1)$ & $(47.3)$ & $(45.0)$ & $(56.9)$ & $(55.7)$ & $(48.3)$ & $(54.0)$ & $(45.5)$ & $(52.4)$ \\
\hline 1. Non-Food Credit & 4,328 & 4,118 & 4,670 & 6,815 & 6,527 & 6,335 & 7,316 & 5,464 & 7,024 \\
\hline $\begin{array}{l}\text { 2. } \\
\text { Non-SLR Investment by } \\
\text { commercial banks }\end{array}$ & 120 & 93 & 117 & 295 & 246 & 514 & 311 & 386 & 731 \\
\hline \multirow{2}{*}{ B. Flow from Non-Banks $(\mathrm{B} 1+\mathrm{B} 2)$} & 5,646 & 4,686 & 5,850 & 5,392 & 5,383 & 7,335 & 6,505 & 7,005 & 7,052 \\
\hline & $(55.9)$ & $(52.7)$ & $(55.0)$ & $(43.1)$ & $(44.3)$ & $(51.7)$ & $(46.0)$ & $(54.5)$ & $(47.6)$ \\
\hline \multirow[b]{2}{*}{ B1. Domestic Sources } & 2,552 & 2,984 & 3,652 & 3,011 & 3,079 & 4,212 & 4,302 & 4,740 & 4,593 \\
\hline & $(25.3)$ & $(33.5)$ & (34.3) & $(24.1)$ & $(25.3)$ & $(29.7)$ & $(30.4)$ & $(36.9)$ & $(31.0)$ \\
\hline $\begin{array}{ll}\text { 1. } & \text { Public issues by non-financial } \\
\text { entities }\end{array}$ & 515 & 142 & 320 & 285 & 145 & 119 & 199 & 87 & 378 \\
\hline $\begin{array}{ll}2 . & \text { Gross private placements by non- } \\
\text { financial entities }\end{array}$ & 682 & 779 & 1420 & 674 & 558 & 1,038 & 1,314 & 1,277 & 1,095 \\
\hline $\begin{array}{l}\text { 3. Net issuance of CPs subscribed to } \\
\text { by non-banks }\end{array}$ & 107 & 56 & 261 & 68 & 36 & 52 & 138 & 558 & 320 \\
\hline $\begin{array}{l}\text { 4. Net Credit by housing finance } \\
\text { companies }\end{array}$ & 418 & 266 & 285 & 428 & 539 & 859 & 737 & 954 & 1,145 \\
\hline $\begin{array}{l}\text { 5. Total gross accommodation by } 4 \\
\text { RBI regulated Financial } \\
\text { Institutions* }\end{array}$ & 223 & 314 & 338 & 400 & 469 & 515 & 436 & 417 & 446 \\
\hline $\begin{array}{l}\text { 6. Systematically important non- } \\
\text { deposit taking NBFCs (net of bank } \\
\text { credit) }\end{array}$ & 365 & 768 & 607 & 795 & 912 & 1,188 & 1,124 & 1,046 & 840 \\
\hline $\begin{array}{l}\text { 7. LIC's net investment in corporate } \\
\text { debt, infrastructure and Social } \\
\text { Sector }\end{array}$ & 243 & 658 & 422 & 361 & 419 & 441 & 354 & 401 & 369 \\
\hline \multirow{2}{*}{ B2. Foreign Sources } & 3,093 & 1,702 & 2,198 & 2,381 & 2,304 & 3,123 & 2,203 & 2,265 & 2,459 \\
\hline & $(30.6)$ & (19.1) & $(20.7)$ & $(19.0)$ & $(19.0)$ & $(22.0)$ & $(15.6)$ & (17.6) & $(16.6)$ \\
\hline $\begin{array}{l}\text { 1. External Commercial Borrowings / } \\
\text { FCCB }\end{array}$ & 912 & 380 & 120 & 539 & 421 & 466 & 661 & 14 & -388 \\
\hline $\begin{array}{ll}\text { 2. } & \text { ADR/GDR Issues excluding banks } \\
\text { and financial institutions }\end{array}$ & 118 & 48 & 151 & 92 & 27 & 10 & 1 & 96 & 0 \\
\hline 3. Short-term Credit from abroad & 689 & -312 & 349 & 426 & 306 & 1,177 & -327 & -4 & -96 \\
\hline 4. Foreign Direct Investment to India & 1374 & 1586 & 1578 & 1324 & 1,550 & 1,470 & 1,868 & 2,159 & 2,943 \\
\hline \multirow{2}{*}{ C. Total Flow of Resources $(A+B)$} & 10,094 & 8,897 & 10,636 & 12,503 & 12,156 & 14,184 & 14,132 & 12,855 & 14,806 \\
\hline & $(100.0)$ & $(100.0)$ & $(100.0)$ & $(100.0)$ & $(100.0)$ & $(100.0)$ & $(100.0)$ & $(100.0)$ & $(100.0)$ \\
\hline
\end{tabular}




\begin{tabular}{|l|l|l|l|l|l|l|l|}
\hline \multicolumn{9}{|c|}{ Table 7: Resources Mobilized by Corporate Sector (Public, Rights and Private Placements): Monthly Averages } \\
(Rs. Billion)
\end{tabular}

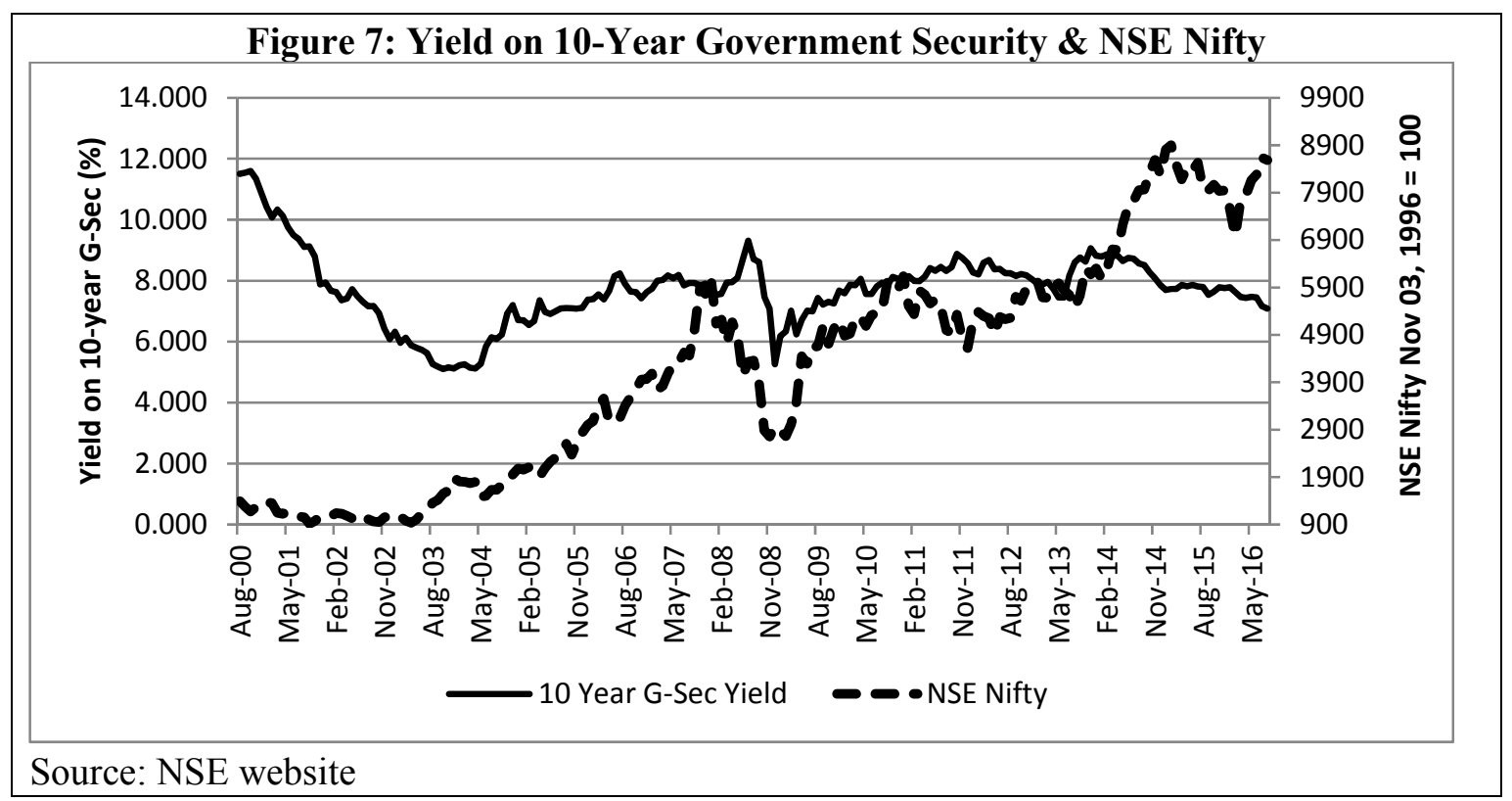

\section{Bond / Debt Market}

Traditionally the bond market is differentiated on the basis of ownership viz., government bonds and corporate bonds. The story of Government bond market is intimately interlinked with the evolution of fiscal policy in India. A system of unbridled deficit financing via fixed coupon ad-hoc Treasury bill market has been transformed into a market driven auction process in electronic platform by late 1990s. Institutionally, creation of primary dealers (PDs) to function as market makers (both in primary and secondary markets) in government bond market since 1995 is a major development in this sector (Mohan and Ray, 2011). With increased volume of transactions liquidity in this market have increased as well (Table 8).

In contrast, the corporate debt market in India has been far less developed. Much of the transactions in this market are concentrated in the bonds of blue-chip corporates and the market is predominantly a private placement market with limited liquidity (Table 7). There are several reasons for this. First, large corporates often tend to go abroad for their longer- 
term borrowing requirements. Second, on the demand side, with the pension and insurance industries being in their infancy, there are a very limited number of institutional investors with limited funds. Third, limited availability of other investors also could have influenced the size of the debt market. While this is in line with international experience, several official committees have looked into this issue but in terms of ground reality things have not changed substantially. In terms of outturn, the market size at around 15 percent of GDP is much smaller than bank assets ( 89 percent of GDP) and equity markets ( 80 percent of GDP).

\begin{tabular}{|c|c|c|c|c|c|c|c|c|}
\hline \multicolumn{9}{|c|}{$\begin{array}{l}\text { Table 8: Turnover In Government Securities Market (Face Value): Weekly Average } \\
\text { (Rs. Billion) }\end{array}$} \\
\hline \multirow[t]{2}{*}{ Year } & \multirow{2}{*}{$\begin{array}{r}\text { Central } \\
\text { Government } \\
\text { Dated } \\
\text { Securities }\end{array}$} & \multirow{2}{*}{$\begin{array}{r}\text { State } \\
\text { Government } \\
\text { Dated } \\
\text { Securities }\end{array}$} & \multicolumn{5}{|c|}{ Treasury bills } & \multirow[t]{2}{*}{ RBI } \\
\hline & & & $\begin{array}{r}\text { Cash } \\
\text { Management } \\
\text { bills }\end{array}$ & 14 - Day & 91-Day & 182 -day & $\begin{array}{r}364- \\
\text { Day }\end{array}$ & \\
\hline $2000-01$ & 195 & 1 & -- & 2 & 3 & 2 & 16 & 6 \\
\hline $2001-02$ & 435 & 2 & -- & 2 & 8 & 1 & 18 & 8 \\
\hline $2002-03$ & 496 & 3 & -- & -- & 13 & -- & 16 & 10 \\
\hline 2003-04 & 597 & 6 & -- & -- & 19 & -- & 26 & 8 \\
\hline 2004-05 & 340 & 10 & -- & -- & 51 & -- & 46 & 1 \\
\hline $2005-06$ & 218 & 7 & -- & -- & 24 & 8 & 41 & 1 \\
\hline $2006-07$ & 95 & 5 & -- & - & 13 & 11 & 23 & 1 \\
\hline $2007-08$ & 338 & 6 & -- & -- & 20 & 10 & 26 & 4 \\
\hline 2008-09 & 752 & 14 & -- & -- & 43 & 7 & 18 & 22 \\
\hline $2009-10$ & 972 & 29 & -- & -- & 105 & 15 & 25 & 20 \\
\hline $2010-11$ & 996 & 20 & 38 & -- & & 16 & 21 & 21 \\
\hline $2011-12$ & 1190 & 20 & 23 & -- & 73 & 20 & 34 & 32 \\
\hline $2012-13$ & 2277 & 46 & -- & -- & 96 & 43 & 80 & 34 \\
\hline 2013-14 & 3086 & 61 & 126 & -- & 125 & 61 & 118 & 19 \\
\hline $2014-15$ & 3520 & 72 & 28 & -- & 160 & 56 & 98 & 21 \\
\hline $2015-16$ & 3246 & 123 & -- & -- & 185 & 54 & 88 & 45 \\
\hline
\end{tabular}

\section{Equity Market}

The Indian equity market has undergone a radical transformation since the initiation of financial sector reforms since the early 1990s. The reform measures were aimed at, "(i) creating growth-enabling institutions; (ii) boosting competitive conditions in the equity market through improved price discovery mechanism; (iii) putting in place an appropriate regulatory framework; (iv) reducing the transaction costs; and (v) reducing information asymmetry, thereby boosting the investor confidence" (RBI, 2007).

A key reform this respect repealing of the Capital Issues (Control) Act, 1947 in 1992 whereby the process of raising capital from the market has been liberalized. Nevertheless, after the capital market scandal of 1992, a regulatory structure was put in place gradually. Illustratively, the norms for public issues were made stringent in April 1996, and there was substantial improvement in disclosure requirement. Several other initiatives were also undertaken, such as, introduction of the option of raising resources through fixed price mechanism or the book building process; on-line screen based electronic trading with gradual 
move towards a two-day $(\mathrm{T}+2)$ settlement; establishment of National Securities Depository Ltd. (NSDL) in 1996 and Central Depository Services (India) Ltd. (CSDL) in 1999 enabling paperless trading; and introduction of trading in derivatives such as stock index futures, stock index options and futures and options (RBI, 2007).

The success story of the Indian equity market has been driven by two major institutions, both established under government auspicious, viz., Securities and Exchange Board of India (SEBI) and the National Stock Exchange (NSE). While SEBI, the securities market regulator, was established in 1988, it was given statutory powers in April 1992 through the SEBI Act, 1992, which set out its basic functions as, "...to protect the interests of investors in securities and to promote the development of, and to regulate the securities market and for matters connected therewith or incidental thereto." Thus, SEBI is the overall capital market regulator charged with the orderly functioning of the securities market.

Though the more traditional stock market, the BSE (formerly known as Bombay Stock Exchange) was established as early as 1875 , it was essentially a mutualized exchange and was not modernized. The NSE was established in 1992 as the first demutualized electronic exchange in India. Over time, the NSE emerged as a modern electronic trading platform and took new initiatives to introduce derivative trading in India. Though subsequently, BSE too has modernized, at the current juncture the NSE (and in particular its derivative segment) has the lion's share of the equity market turnover (Table 9).

\begin{tabular}{|c|c|c|c|c|c|c|c|c|c|c|c|}
\hline \multicolumn{12}{|c|}{ Table 9: Turnover in Equity Market (Rs Billion) } \\
\hline Year & BSE & $\mathrm{NSE}$ & \multicolumn{4}{|c|}{ Bombay Stock Exchange Limited (BSE) } & \multicolumn{5}{|c|}{ National Stock Exchange of India Limited (NSE) } \\
\hline & $\begin{array}{r}\text { Spot } \\
\text { Market }\end{array}$ & $\begin{array}{r}\text { Spot } \\
\text { Market }\end{array}$ & $\begin{array}{r}\text { Index } \\
\text { Futures }\end{array}$ & $\begin{array}{r}\text { Index } \\
\text { Options }\end{array}$ & $\begin{array}{r}\text { Stock } \\
\text { Futures }\end{array}$ & $\begin{array}{r}\text { Stock } \\
\text { Options }\end{array}$ & $\begin{array}{r}\text { Index } \\
\text { Futures }\end{array}$ & $\begin{array}{r}\text { Index } \\
\text { Option } \\
\mathrm{s}\end{array}$ & $\begin{array}{r}\text { Stock } \\
\text { Futures }\end{array}$ & $\begin{array}{r}\text { Stock } \\
\text { Options }\end{array}$ & $\begin{array}{r}\text { Interest } \\
\text { Rate } \\
\text { Futures }\end{array}$ \\
\hline $1990-91$ & 360 & & & & & & & & & & \\
\hline $1991-92$ & 718 & & & & & & & & & & \\
\hline $1992-93$ & 457 & & & & & & & & & & \\
\hline 1993-94 & 845 & & & & & & & & & & \\
\hline $1994-95$ & 677 & 18 & & & & & & & & & \\
\hline $1995-96$ & 501 & 673 & & & & & & & & & \\
\hline $1996-97$ & 1243 & 2945 & & & & & & & & & \\
\hline $1997-98$ & 2076 & 3702 & & & & & & & & & \\
\hline $1998-99$ & 3120 & 4145 & & & & & & & & & \\
\hline 1999-00 & 6850 & 8391 & & & & & & & & & \\
\hline $2000-01$ & 10000 & 13395 & $1 \overline{\overline{7}}$ & $\overline{0}$ & 0 & $\overline{0}$ & 24 & _- & - & - & - \\
\hline $2001-02$ & 3073 & 5132 & 13 & 1 & 5 & 1 & 215 & 38 & 515 & 252 & - \\
\hline $2002-03$ & 3141 & 6180 & 18 & 0 & 6 & 0 & 440 & 92 & 2865 & 1001 & - \\
\hline 2003-04 & 5026 & 10995 & 66 & 0 & 52 & 3 & 5544 & 528 & 13059 & 2172 & - \\
\hline $2004-05$ & 5187 & 11401 & 136 & 23 & 2 & 0 & 7721 & 1219 & 14840 & 1688 & - \\
\hline $2005-06$ & 8161 & 15635 & 0 & 0 & 0 & 0 & 15138 & 3385 & 27917 & 1802 & - \\
\hline $2006-07$ & 9562 & 19453 & 555 & 0 & 35 & 0 & 25396 & 7919 & 38310 & 1938 & - \\
\hline $2007-08$ & 15789 & 35510 & 2347 & 0 & 76 & 0 & 38207 & 13621 & 75486 & 3591 & - \\
\hline $2008-09$ & 11001 & 27520 & 118 & 0 & 0 & 0 & 35701 & 37315 & 34796 & 2292 & - \\
\hline $2009-10$ & 13788 & 41380 & 1 & 1 & 0 & 0 & 39344 & 80279 & 51952 & 5061 & - \\
\hline $2010-11$ & 11035 & 35774 & 2 & 0 & 0 & 0 & 43568 & 183654 & 54957 & 10303 & - \\
\hline 2011-12 & 6670 & 28109 & 1783 & 6183 & 100 & 14 & 35780 & 227200 & 40747 & 9770 & - \\
\hline $2012-13$ & 5488 & 27083 & 1214 & 70275 & 34 & 102 & 25271 & 227816 & 42239 & 20004 & - \\
\hline 2013-14 & 5217 & 28085 & 635 & 90552 & 546 & 461 & 30831 & 277673 & 49492 & 24094 & 302 \\
\hline 2014-15 & 8551 & 43258 & 486 & 201292 & 98 & 1751 & 41072 & 399227 & 82918 & 32825 & 4215 \\
\hline $2015-16$ & 7195 & 41153 & 131 & 43863 & 13 & 743 & 45571 & 489519 & 78286 & 34881 & 5264 \\
\hline $\begin{array}{r}\text { Notes: } \\
\text { (1) } \\
(2) \\
\\
(3) \\
\text { (4) } \\
\text { Source: }\end{array}$ & $\begin{array}{l}\text { BSE: Bomba } \\
\text { Index future } \\
2001 \text {, both ir } \\
\text { Notional tur } \\
\text { The RBI has } \\
\text { BI database o }\end{array}$ & $\begin{array}{l}\text { Stock Ex } \\
\text { were intro } \\
\text { the BSE a } \\
\text { yer inclu } \\
\text { ntroduced } \\
\text { Indian E }\end{array}$ & $\begin{array}{l}\text { hange Li1 } \\
\text { luced in J } \\
\text { d NSE, w } \\
\text { es call an } \\
\text { cash settle } \\
\text { onomy. }\end{array}$ & $\begin{array}{l}\text { d; NSE: N } \\
2000 \text {, inde } \\
\text { interest ra } \\
\text { t options; } \\
\text { terest rate }\end{array}$ & $\begin{array}{l}\text { nal Stock } \\
\text { ptions in Ju } \\
\text { utures wer } \\
\text { ures on } 10\end{array}$ & $\begin{array}{l}\text { ehange of } \\
\text { e } 2001 \text {, sto } \\
\text { introduced }\end{array}$ & $\begin{array}{l}\text { lia Limited } \\
\text { options in } \\
\text { NSE in Ju } \\
\text { ecember } 5\end{array}$ & $\begin{array}{l}2003 \\
2013\end{array}$ & d stock fu & res in Nov & nber \\
\hline
\end{tabular}


The Indian equity market has witnessed significant improvement, since the early 1990 s - this is reflected in metrics such as, size of the market, liquidity, transparency, stability and efficiency. Illustratively, despite its volatility, India's market capitalization to GDP ratio stood nearly 70 percent at the end of 2016 but its share of global market capitalization was only 2.3 percent at the end of 2015 (Figure 8 ). Changes in the regulatory and governance framework have brought about significant improvement in investor confidence over time (RBI, 2007).

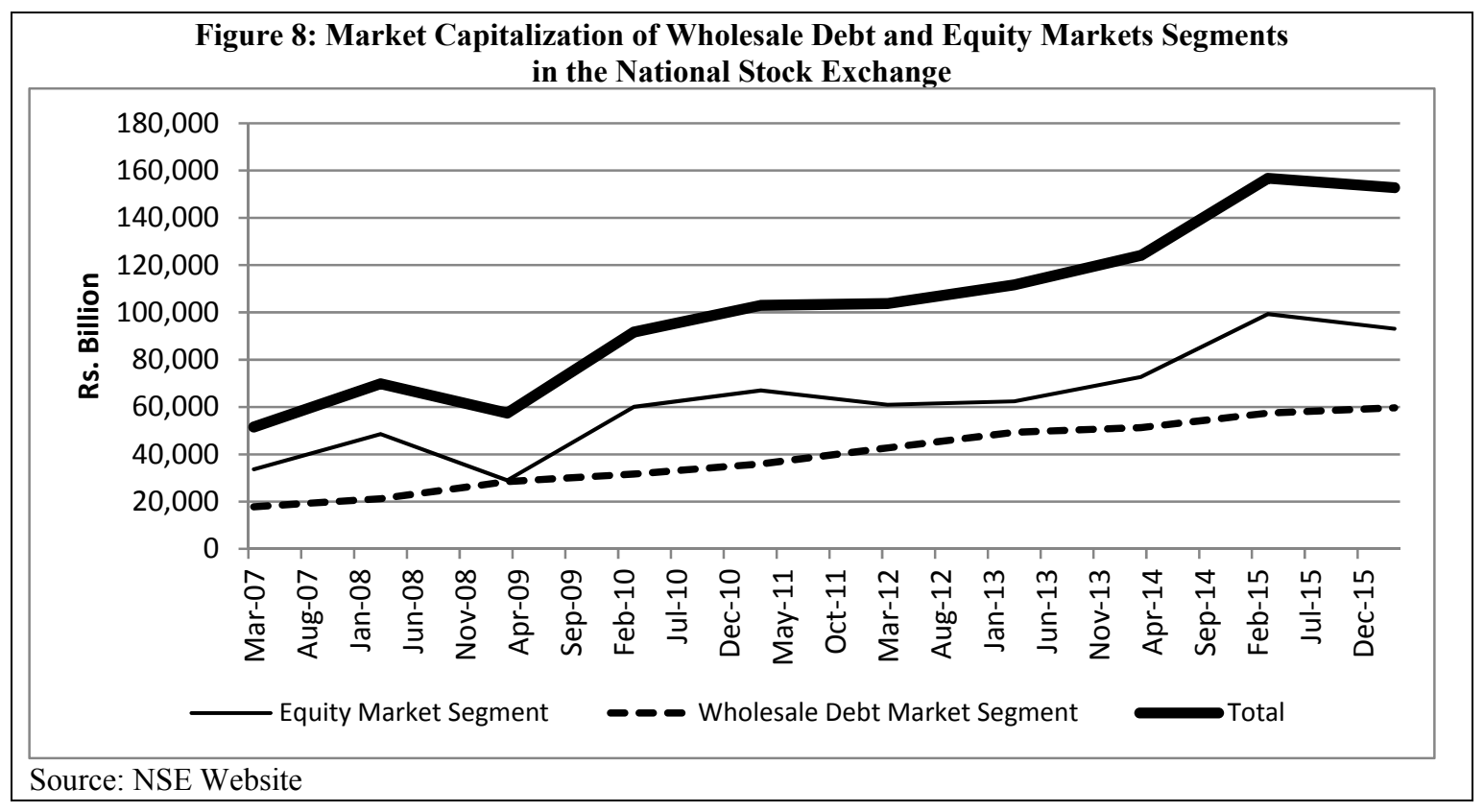

\section{Mutual Funds (MFs) —The Early Reformer}

A mutual fund is a mechanism for pooling resources by issuing units to investors and then investing funds in securities, in both equity and debt. The MFs as a group have tended to play played a very important role in the Indian capital market. During 1963-1988, the Unit Trust of India (UTI) had a monopoly in the MF industry and its assets under management grew to about Rs. 67 billion by 1988. The reform process of the MF industry started in 1988 when non-UTI, public sector mutual funds set up by public sector banks, the LIC and the GIC entered the market. Subsequently, private sector funds were allowed to enter the MF industry in 1993. The issuance of the SEBI (Mutual Fund) Regulations in 1996 paved the way for further operational freedom for the players in the MF industry. By January 2003, there were 33 mutual fund companies with total assets of Rs. 1.2 trillion- of which the UTI's share was little more than one-third.

The US-64 scheme of the UTI ran into difficulty in 2001, which resulted in the next rounds of reforms. The UTI was bifurcated into two separate entities - one broadly representing the assets of the then US-64 scheme, assured return and certain other schemes, and the other called the UTI Mutual Fund (sponsored by select public sector banks and the LIC) which operates like any other MF. As of March, 2016 there were 44 asset management companies in the country with assets under management (AUM) of around Rs. 13.5 trillion (or 10 percent of GDP), which though high, is far below the deposits of the commercial banks (at about Rs. 99 trillion or 73 percent of GDP) (ICRA, 2016). In terms of net inflows, the 
share of private sector MFs far exceeded that of public sector MFs (Table 10). While the growth in the MF industry has been shared both by debt oriented schemes as well as equity oriented schemes, MFs in recent past have shown a preference for debt oriented schemes. Interestingly, the share of the retail investors (includes the retail and high net-worth individuals) of AUM of the MFs was 48.5 percent with the rest (51.5 percent) coming from the institutional investors (includes corporates, Banks/FI's and the FII's) ${ }^{21}$ In a country where direct investments by households in equity and debt market are meager, MFs have a huge potential to grow. The recent growth in 'assets under management' of the MF industry from 16 non-metro towns /cities bears testimony to this.

\begin{tabular}{|c|c|c|c|c|c|}
\hline \multicolumn{6}{|c|}{ Table 10: Net Resources Mobilized By Mutual Funds (Rs. Billion) } \\
\hline Year & $\begin{array}{r}\text { Unit Trust of } \\
\text { India }\end{array}$ & $\begin{array}{r}\text { Bank-sponsored } \\
\text { Mutual Funds }\end{array}$ & $\begin{array}{r}\text { Financial } \\
\text { Institution- } \\
\text { sponsored Mutual } \\
\text { Funds }\end{array}$ & $\begin{array}{l}\text { Private Sector } \\
\text { Mutual Funds }\end{array}$ & Total \\
\hline 1990-91 & 45.53 & 23.52 & 6.04 & - & 75.09 \\
\hline 1991-92 & 86.85 & 21.40 & 4.28 & - & 112.53 \\
\hline $1992-93$ & 110.57 & 12.04 & 7.60 & - & 130.21 \\
\hline $1993-94$ & 92.97 & 1.48 & 2.38 & 15.60 & 112.43 \\
\hline 1994-95 & 86.11 & 7.66 & 5.76 & 13.22 & 112.75 \\
\hline $1995-96$ & -63.14 & 1.13 & 2.35 & 1.33 & -58.33 \\
\hline $1996-97$ & -30.43 & 0.07 & 1.37 & 8.64 & -20.35 \\
\hline $1997-98$ & 28.75 & 2.37 & 2.04 & 7.49 & 40.65 \\
\hline 1998-99 & 1.70 & -0.89 & 5.47 & 20.67 & 26.95 \\
\hline 1999-00 & 45.48 & 3.36 & 2.96 & 169.38 & 221.18 \\
\hline $2000-01$ & 3.22 & 2.49 & 12.73 & 92.92 & 111.36 \\
\hline 2001-02 & -72.84 & 8.63 & 4.06 & 161.34 & 101.19 \\
\hline 2002-03 & -94.34 & 10.33 & 8.61 & 121.22 & 45.82 \\
\hline 2003-04 & 10.50 & 45.26 & 7.87 & 415.10 & 478.73 \\
\hline 2004-05 & -24.67 & 7.06 & -33.84 & 79.33 & 27.88 \\
\hline 2005-06 & 34.24 & 53.65 & 21.12 & 415.81 & 524.82 \\
\hline $2006-07$ & 73.26 & 30.33 & 42.26 & 794.77 & 940.62 \\
\hline $2007-08$ & 106.78 & 75.97 & 21.78 & 1382.24 & 1586.77 \\
\hline $2008-09$ & -41.12 & 44.89 & 59.54 & -305.38 & -242.08 \\
\hline 2009-10 & 156.53 & 98.55 & 48.71 & 479.68 & 783.47 \\
\hline $2010-11$ & -166.36 & 13.04 & -169.88 & -162.81 & -486.00 \\
\hline 2011-12 & -31.79 & 3.89 & -30.98 & -395.25 & -454.13 \\
\hline $2012-13$ & 46.29 & 67.08 & 22.41 & 652.84 & 788.62 \\
\hline 2013-14 & 4.01 & 48.45 & 25.72 & 467.61 & 545.79 \\
\hline $2014-15$ & -12.78 & -7.00 & -10.35 & 1123.9 & 1093.77 \\
\hline \multicolumn{6}{|c|}{$\begin{array}{l}\text { Notes } \\
\text { 1. Data for 2014-15 are provisional. } \\
\text { 2. For Unit Trust of India (UTI), data are gross values (with premium) of net sales under all domestic schemes. } \\
\text { 3. Data for UTI for 2003-04 relates to UTI Mutual Fund for the period from February 01, } 2003 \text { to March 31, 2004, being the } \\
\text { first year in operation after the bifurcation of the erstwhile UTI into UTI Mutual Fund and Specified Undertaking of the Unit } \\
\text { Trust of India. Subsequent annual data (from 2004-05 onwards) pertain to UTI Mutual Fund only. }\end{array}$} \\
\hline
\end{tabular}

\section{Pension Funds: A Late Entrant}

India, like most of the developing economics, does not have a universal social security system and the pension system has largely catered to the organized segment of the labor force. While, till recently, public sector / government employees typically had a three-fold structure

${ }^{21}$ The large share of corporate entities in debt mutual funds has perhaps been caused by the prohibition of interest bearing bank deposits. Further, interest is not permitted in bank deposits of less than 7 days. 
comprising provident fund, gratuity ${ }^{22}$ and pension schemes, the bulk of the private sector (with the sole exception of the major corporates) had access only to provident funds, a defined-contribution, fully funded benefit program providing lump sum benefits at the time of retirement. The Employees' Provident Fund (EPF) is the largest benefit program operating in India. Reflecting this state of affairs, the significance of pension funds in the Indian financial sector has been rather limited. In terms of size India's pension funds stood at 0.3 percent of its GDP, as against China's 1 percent or Brazil's 13 percent (OECD, 2015).

The pension funds sector has undergone significant reforms. In recognition of the possibility of an unsustainable fiscal burden in the future, the Government of India moved from a defined-benefit pension system to a defined-contribution pension system, called the "New Pension System" (NPS) in January 2004. While the Government constituted an interim regulator, the Interim Pension Fund Regulatory and Development Authority (PFRDA) to regulate the pension sector in 2003, it finally started functioning as a statutory regulator for the NPS in 2014. As of March 2016, there were 8.7 million subscribers with assets under management (AUM) amounting to Rs. 1.18 trillion. Under the present scheme, a subscriber has the option to select any one of the 8 pension funds, which are primarily floated by public sector banks and/or insurance companies. Considering the fact that India's population is around 1.25 billion in which the share of the old (i.e., 60 years and above) is around 10 percent, pension funds in India have, in principle, a large potential - both as a social security measure as well as means to providing a depth to the financial markets, in both debt and equity market segments. Going forward, pension funds will emerge as sources of funds in infrastructure and other projects with long gestation period, as well as for providing depth to the equity market (perhaps looking for absorbing stocks arising out of disinvestment program of the government).

\section{External Account and India's Financial Opening}

It needs to be noted that India has generally incurred a current account deficit which has been financed by foreign direct and portfolio investment and by various kinds of debt flows including external commercial borrowing, portfolio flows and official borrowing. Significant changes have taken place in the management of the external sector since the early 1990s.

The exchange rate regime moved from a basket-based pegged exchange rate to a market determined, but managed, exchange rate in 1993, paving the way for current account convertibility in 1994. In line with the substantial liberalization of capital account transactions over time, India's exchange rate arrangement has been classified as "floating" but with significant degree of capital account management (IMF, 2014). While the details of such control is beyond the scope of the present paper, it needs to be noted that almost all the financial markets witnessed significant entry of foreign players but at a varied and calibrated pace (Mohan and Kapur, 2011). The Indian approach to capital account management is best summarized as follow:

"In its approach to opening of the capital account, Indian clearly recognized a hierarchy in capital flows. It has favoured equity flows over debt flows and foreign direct investment over portfolio investment. The Indian capital market has been opened to institutional portfolio flows, but with some limits on

${ }^{22}$ Gratuity refers to the lump-sum amount payable to the retiring Government servant; a minimum of 5 years qualifying service and eligibility to receive service gratuity / pension is essential to get this one time lump sum benefit. 
shares of domestic companies that can be held by foreign portfolio investors, both individually and collectively. Apart from some limits on the proportion of equity held by non-residents in certain sensitive sectors, FDI is now almost fully open.

A more cautious approach was followed with regard to debt flows. Portfolio investment in both corporate and government debt are governed by overall quantitative limits; the non-financial corporate sector's access to external debt was liberalized gradually, but is subject to adherence to criteria related to purpose, interest rate spreads and magnitude of borrowing. These controls have been modified from time to time depending on the volume of capital flows. The access of financial sector intermediaries has been subject to more prudential restrictions in recognition of the greater hazards associated with such external borrowing.

Capital outflows were also been liberalised progressively. All inflows by non-residents are freely repatriable. Resident non-financial companies have been enabled to invest abroad relatively freely with few restrictions. Individuals can also invest abroad but within specified quantitative limits. Individuals are, however, not permitted to borrow abroad" (Mohan and Kapur, 2011).

Thus, foreign players have a greater presence in the equity market than the debt market. This calibrated pace of capital account convertibility of the Indian authorities has, however, been seen as slow/conservative in some quarters (Shah and Patnaik, 2008).

Development of the forex market has been a key ingredient of India's external sector. Market participants have been provided with greater flexibility to undertake foreign exchange operations through simplification of procedures and availability of several new instruments. There has also been significant improvement in market infrastructure in terms of trading platform and settlement mechanisms. As a result of various reform measures, turnover in the foreign exchange market experienced a quantum jump and the bid-ask spreads have experienced significant declines. Apart from the spot segment, derivatives segment has also emerged (Figure 9). For example, in beginning of May 2016, the spot as well as swap interbank transaction together exceeded USD 8.6 billion. While their presence in different segments of the financial market has added significant depth, they have also contributed to volatility from time to time. ${ }^{23}$

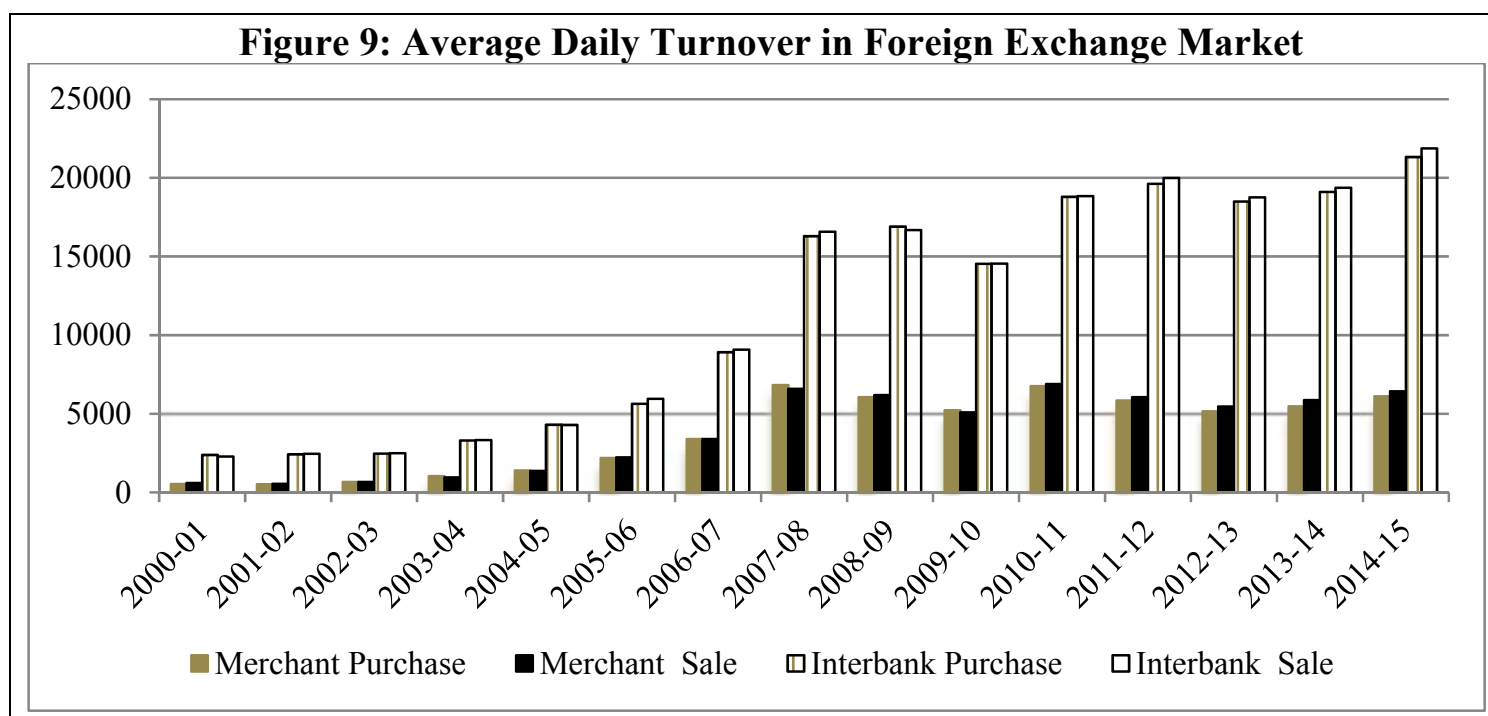

Source: Database on Indian Economy, RBI

\footnotetext{
${ }^{23}$ For example, the episode of sharp depreciation of the Indian rupee (INR) during June-August 2013 was primarily triggered by outflow of FII investment (both debt and equity), following the tapering hints of the US Fed. The rupee-US dollar exchange rate came down sharply from 56.765 in the beginning of June 2013 to 67.8787 on August 29, 2013.
} 
Since 1992, foreign portfolio investors (FPIs) in general and foreign institutional investors (FIIs), in particular, were allowed to invest in both equity and debt instruments. ${ }^{24}$ Besides, Indian corporates were allowed to access international capital markets through American Depository Receipts (ADRs), Global Depository Receipts (GDRs), Foreign Currency Convertible Bonds (FCCBs) and External Commercial Borrowings (ECBs). Over the years, while foreign institutional investors (FIIs) have emerged as key players in India's debt, equity and forex markets, there has been considerable volatility in these flows (Table 11).

\begin{tabular}{|l|r|r|r|}
\hline \multicolumn{4}{|c|}{ Table 11: Foreign Investment in India } \\
\hline Year & $\begin{array}{r}\text { Foreign Investment/ } \\
\text { Exports }\end{array}$ & Foreign Investment/ & Net Investments by FII \\
& $(\%)$ & (Rs. Billion) \\
& $(\%)$ & 0 \\
\hline $1992-93$ & 3.0 & 0.2 & 55 \\
\hline $1993-94$ & 18.7 & 1.5 & 48 \\
\hline $1994-95$ & 18.3 & 1.5 & 67 \\
\hline $1995-96$ & 14.9 & 1.3 & 74 \\
\hline $1996-97$ & 18.0 & 1.6 & 59 \\
\hline $1997-98$ & 15.1 & 1.3 & -7 \\
\hline $1998-99$ & 7.0 & 0.6 & 98 \\
\hline $1999-00$ & 13.8 & 1.2 & 97 \\
\hline $2000-01$ & 14.9 & 1.5 & 83 \\
\hline $2001-02$ & 18.2 & 1.7 & 27 \\
\hline $2002-03$ & 11.2 & 1.2 & 440 \\
\hline $2003-04$ & 23.7 & 2.6 & 414 \\
\hline $2004-05$ & 18.0 & 2.1 & 487 \\
\hline $2005-06$ & 20.3 & 2.6 & 238 \\
\hline $2006-07$ & 23.1 & 3.1 & 626 \\
\hline $2007-08$ & 37.3 & 5.0 & -433 \\
\hline $2008-09$ & 14.8 & 2.3 & 1149 \\
\hline $2009-10$ & 35.9 & 4.8 & 1108 \\
\hline $2010-11$ & 23.6 & 3.5 & 499 \\
\hline $2011-12$ & 16.3 & 2.8 & 1406 \\
\hline $2012-13$ & 17.8 & 3.0 & 0 \\
\hline $2013-14$ & 11.2 & 1.9 & 55 \\
\hline $2014-15$ & 24.5 & 3.8 & 48 \\
\hline $2015-16$ & 15.5 & 2.0 & \\
\hline Source: Database on Indian & & & \\
\hline
\end{tabular}

While there is little restriction on Foreign Direct Investment (FDI), excepting print \& media, and real estate, there are still some restrictions on Foreign Portfolio Investment (FPI). As far as equity is concerned, portfolio investment has virtually unrestricted access there are aggregate limits on FPI in sovereign as well as corporate debt. Of course these limits have been progressively increased over time. In recent times, Indian authorities have been adopting

\footnotetext{
${ }^{24}$ Foreign Portfolio Investors would include Asset Management Companies, Pension Funds, Mutual Funds, and Investment Trusts as Nominee Companies, Incorporated / Institutional Portfolio Managers or their Power of Attorney holders, University Funds, Endowment Foundations, Charitable Trusts and Charitable Societies
} 
a policy of channelizing FPI into debt instruments of a certain minimum maturity in view of credit and interest rate risks. Besides, the regulatory regime for external borrowing had the following broad components: (a) restriction on short term (less than three years) borrowing; (b) a loosely monitored overall aggregate limit on foreign currency liability; (c) a discriminatory regime channeling flow into the priority sectors and disallowing flow into sensitive sectors such as real estate; and (d) a cap on the overall cost of borrowing, as a tool to address the adverse selection problem (Padmanabhan, 2015).

\section{Non-Banking Finance Companies (NBFCs)—Checkered Trend}

Apart from the banks, India has a number of non-banking financial companies (NBFCs). The fundamental difference between banks and NBFCs in India are three: (a) NBFCs cannot accept demand deposits; (b) NBFCs do not form part of the payment and settlement system and cannot issue checks drawn on itself; and (c) deposit insurance facility is not available to depositors of NBFCs, unlike in case of banks. The NBFCs is far from being a homogenous entity and include many diverse types of financial institutions from a housing finance company to an equipment leasing company. ${ }^{25}$ The diversity among the entities of the NBFC sector is also reflected in attributes like sizes and the extent of regulatory oversight. As of March 2016, there were 11,682 NBFCs registered with the RBI, of which 202 were deposit-accepting and 11,480 were non-deposit accepting NBFCs, of which 220 were declared as systemically important (i.e., those with an asset size of Rs one billion or more). ${ }^{26}$ In the popular discourse the role of NBFCs are seen from two distinct angles: (a) they have been very useful for sectors / activities that are generally excluded from formal banking activities; and (b) at some regularity some of the deposit raking NBFCs have been source of financial irregularity in some localized pockets and raised the issue of consumer protection.

Although NBFCs have existed for a long time in India, these entities experienced sudden spurt in their activities between the late 1980s and the mid-1990s. While, on an average basis, deposits of NBFCs as a proportion of bank deposits were 0.8 percent during 1985-86 to 1989-90, they shot up to as much as 9.5 percent by 1996-97. This sharp jump in NBFC deposits was mostly, "on account of the high rates of interest offered on such deposits" (RBI, 2003). There been sporadic incidence of financial irregularities as well. While traditionally, the regulation of NBFCs was confined to deposit-taking activities of NBFCs, in 1997 the RBI was given comprehensive powers to regulate NBFCs. The amended RBI Act made it mandatory for every NBFC to have minimum net owned funds (NOF) and obtain a certificate of registration from the RBI for commencing or carrying on business. At the current juncture, while a large chunk of deposit and non-deposit taking financial companies (viz., (i) to (x) in the list given in the footnote) are regulated by the RBI, housing finance companies are regulated by National Housing Bank, Chit Funds are regulated by the State Governments, and Mutual Benefit companies are regulated by Ministry of Corporate Affairs, Government of India. This multiplicity of regulators has always become an issue in their functioning.

\footnotetext{
${ }^{25}$ These include: (i) Asset Finance Companies (AFCs); (ii) Loan Companies (LCs); (iii) Investment Companies (ICs); (iv) Infrastructure Finance Companies (IFCs); (v) Core Investment Companies (CICs); (vi) Infrastructure Debt Funds (IDF-NBFCs); (vii) NBFC-Microfinance Institutions (NBFC-MFIs); (viii) Factoring companies (FCs); (ix) Mortgage Guarantee Companies (MGCs); (x) Residuary Non-Banking Companies (RNBCs); (xi) Housing Finance Companies; (xii) Mutual Benefit Companies; and (xiii) Chit Fund companies.

${ }^{26}$ See the RBI "Master Circulars- Miscellaneous Instructions to NBFC- ND-SI" of July 01, 2015; available at https://rbi.org.in/scripts/BS ViewMasCirculardetails.aspx?id=9835
} 
Thus, there has been a cleaning process of the NBFC sector since 1998 so that the shadow banking sector could not overshadow the traditional banking business in India. Illustratively, presently all deposit taking NBFCs and systemically important non-deposit taking NBFCs are subject to prudential regulations such as capital adequacy requirements and provisioning norms along with reporting requirements.

While a number of types of NBFCs exist, which do not come under the ambit of RBI's regulatory oversight, the incidence of financial irregularity involving some NBFCs had come down and had predominantly been confined to the state / district-level. ${ }^{27}$ In fact, in recent past after a financial scandal involving an NBFC named Saradha (predominantly active in the state of West Bengal) surfaced in 2013, there has been further tightening of norms on deposit taking NBFCs.

Interestingly, in line with the increasing regulatory control, over the years, while acceptance of deposits by the NBFCs had come down, there were fewer lulls in their other activities. Illustratively, the ratio of NBFCs' assets in GDP increased steadily from just 8.4 percent as on March 31, 2006 to 12.9 percent as on March 31, 2015; while the ratio of bank assets increased from 75.4 percent to 96.4 percent during the same period (Table 12).

\begin{tabular}{|c|c|c|c|c|c|c|c|c|}
\hline \multicolumn{9}{|c|}{$\begin{array}{l}\text { Table 12: Deposit-taking Activities of NBFCs } \\
\text { (in Rs billion) }\end{array}$} \\
\hline Year & \multicolumn{2}{|c|}{ NBFCs } & \multicolumn{2}{|c|}{ RNBC } & \multirow{2}{*}{$\begin{array}{c}\text { Total } \\
\text { Public } \\
\text { Deposits of } \\
\text { NBFCs }\end{array}$} & \multicolumn{3}{|c|}{ Memo Items } \\
\hline & $\begin{array}{r}\text { No of } \\
\text { Reporting } \\
\text { Companies }\end{array}$ & $\begin{array}{r}\text { Public } \\
\text { Deposits }\end{array}$ & $\begin{array}{r}\text { No of } \\
\text { Reporting } \\
\text { Companies }\end{array}$ & $\begin{array}{r}\text { Public } \\
\text { Deposits }\end{array}$ & & $\begin{array}{c}\text { Public deposits } \\
\text { of NBFCs as } \% \\
\text { of bank deposits }\end{array}$ & $\begin{array}{r}N B F C \\
\text { Assets to } \\
\text { GDP (\%) }\end{array}$ & $\begin{array}{r}\text { Commercial } \\
\text { Bank Assets to } \\
\text { GDP (\%) }\end{array}$ \\
\hline $1997-98$ & 1420 & 135.72 & 9 & 102.49 & 238.20 & 4.0 & n.a & n.a \\
\hline 1998-99 & 1536 & 97.85 & 11 & 106.44 & 204.29 & 2.9 & n.a & n.a \\
\hline 1999-00 & 996 & 83.38 & 9 & 110.04 & 193.42 & 2.4 & n.a & $n . a$ \\
\hline $2000-01$ & 974 & 64.59 & 7 & 116.25 & 180.85 & 1.9 & n.a & $\overline{n . a}$ \\
\hline 2001-02 & 905 & 59.33 & 5 & 128.89 & 188.22 & 1.7 & n.a & $n . a$ \\
\hline 2002-03 & 870 & 50.35 & 5 & 150.65 & 201.00 & 1.6 & n.a & n.a \\
\hline 2003-04 & 774 & 43.17 & 3 & 153.27 & 196.44 & 1.3 & n.a & $n . a$ \\
\hline 2004-05 & 700 & 39.26 & 3 & 166.00 & 205.26 & 1.2 & n.a & n.a \\
\hline 2005-06 & 428 & 24.48 & 3 & 201.75 & 226.23 & 1.1 & 8.4 & 75.4 \\
\hline 2006-07 & 401 & 20.77 & 3 & 226.22 & 246.99 & 0.9 & 9.1 & 80.6 \\
\hline $2007-08$ & 364 & 20.42 & 2 & 223.58 & 244.00 & 0.8 & 10.1 & 86.8 \\
\hline 2008-09 & 336 & 19.71 & 2 & 195.95 & 215.66 & 0.6 & 10.3 & 93.0 \\
\hline 2009-10 & 308 & 28.31 & 2 & 145.21 & 173.52 & 0.4 & 10.8 & 93.0 \\
\hline $2010-11$ & 297 & 40.98 & 2 & 79.02 & 120.00 & 0.2 & 10.9 & 92.2 \\
\hline 2011-12 & 271 & 57.35 & 2 & 42.65 & 100.00 & 0.2 & 11.9 & 92.7 \\
\hline $2012-13$ & 254 & 70.85 & 2 & 38.17 & 109.02 & 0.2 & 12.5 & 95.5 \\
\hline 2013-14 & 240 & 108.08 & 2 & 35.82 & 143.90 & 0.2 & 12.5 & 97.4 \\
\hline 2014-15 & 220 & 289.41 & 2 & 31.83 & 321.24 & 0.4 & 12.9 & 96.4 \\
\hline $2015-16$ & 202 & 356.53 & 1 & 15.58 & 372.11 & 0.4 & $n \cdot a$ & n.a \\
\hline
\end{tabular}

Notes:

(1) RNBC (Residuary Non-Banking Company) is a class of NBFC which is a company and has as its principal business the receiving of deposits. These companies are required to maintain investments as per directions of RBI, in addition to liquid assets. The functioning of these companies is different from those of NBFCs in terms of method of mobilization of deposits and requirement of deployment of depositors' funds as per Directions. Besides, Prudential Norms Directions are applicable to these companies also.

(2) Data format has changed after 1996-97 due to new reporting format following changes in the regulatory framework in 1998.

(3) NBFCs include Deposit taking NBFCs (NBFCs-D), Mutual Benefit Financial Companies (MBFCs), Mutual Benefit Companies (MBCs) till 2004-05 and only NBFCs-D thereafter.

Sources: RBI Database on Indian Economy; Vijay Bhaskar (2014); and authors' calculations.

${ }^{27}$ A major financial irregularity in this respect involved a leading NBFC conglomerate, Sahara India Pariwar which was barred by the Securities Market Regulator, SEBI in 2010 from raising money from the public through optionally fully convertible debentures which SEBI deemed illegal. Subsequently, the CEO of the Company was arrested and the Supreme Court of India has directed the Company to pay up RS 240 billion. The case is still subjudice. 


\section{Concluding Observations}

Where does the Indian financial sector stand as of mid-2016? At the risk of broad generalization, the following broad trends could be highlighted as key features of the Indian financial sector. As a consequence of successive reforms over the past 25 years, there has been significant progress in making interest and exchange rates largely market determined, though the exchange rate regime remains one of managed float, and some interest rates remain administered. Considerable competition has been introduced in the banking sector through new private sector banks, but public sector banks continue have a dominant share in the market. Contractual savings systems have been improved, but provident and pension funds in India are still in their infancy. Similarly, despite the introduction of new private sector insurance companies coverage of insurance can expand much further, which would also provide greater depth to the financial markets. The extent of development along all the segments of the financial market has not been uniform. While the equity market is quite developed, activities in the private debt market are predominantly confined to private placement form and continued to be limited to the blue-chip companies. Going forward, the future areas for development in the Indian financial sector would include further reduction of public ownership in banks and insurance companies, expansion of the contractual savings system through more rapid expansion of the insurance and pension systems, greater spread of mutual funds, and development of institutional investors. It is only then that the both the equity and debt markets will display greater breadth as well as depth, along with greater domestic liquidity.

India continues its journey towards a financially inclusive regime through innovative policies involving a multi-pronged approach. India has come a long way from a financially repressive regime to a modern financial sector where public sector financial institutions tend to compete with the private sector financial institutions. The Indian authorities while reforming the financial sector had to constantly keep the issues of equity and efficiency in mind. 


\section{References (all the URLs have been accessed in April-May 2016).}

Ahluwalia, Montek S (1999): “Reforming India's Financial Sector: An Overview”, in James A Hanson and Sanjay Kathuria (eds.): India: a Financial Sector for the Twenty-first Century, New Delhi: Oxford University Press.

Bell, Clive and Peter L. Rousseau. (2001): "Post-independence India: A Case of Finance-Led Industrialization?", Journal of Development Economics, 65(1): 153-75.

Credit Suisse (2015): Report on "House of Debt" (India Research Report), 21 October.

Government of India (1998): Report of the Committee on Banking Sector Reforms (Chairman: M Narasimham), New Delhi: Government of India.

Government of India, (2009): A Hundred Small Steps: Report of the Committee on Financial Sector Reforms (Chairman: Raghuram Rajan), New Delhi: Planning Commission.

Government of India (2015): Report of the Committee to Recommend Measures for Curbing Mis-selling and Rationalising Distribution Incentives in Financial Products" (Chairman: Sumit Bose) available at http://finmin.nic.in/reports/Final_Report_Committee_on_Incentive_Structure.pdf

Government of India (2016): Annual Report: 2015-16 - Department of Posts, available at http://www.indiapost.gov.in/Report/FinalPostAnnualReportEnglish2015-16.pdf

International Monetary Fund (2013): India: Financial Sector Assessment Program-Detailed Assessments Report on IAIS Insurance Core Principles, available at http://www.imf.org/external/pubs/ft/scr/2013/cr13265.pdf

International Monetary Fund (2013a): Guidance Note For The Liberalization and Management Of Capital Flows, available at https://www.imf.org/external/np/pp/eng/2013/042513.pdf

International Monetary Fund (2014): Annual Report on Exchange Arrangements and Exchange Restrictions 2014, Washington DC: IMF.

ICRA (2016): Mutual Fund Screener (for the Quarter ended March 2016), available at https://mutualfundindia.com/Images/Research/PdfPaths/7a11b786a2c942b690db34e7c 39db743Mutual\%20Fund\%20Screener\%20-\%20Mar\%202016.pdf

IRDA (Insurance Regulatory and Development Authority of India) (2007): "History of insurance in India", available at https://www.irdai.gov.in/ADMINCMS

IRDA (2015): Handbook on Indian insurance statistics: 2014-15, Hyderabad: IRDA.

KPMG (2012): Insurance Industry - Road Ahead, available at https://www.kpmg.com/IN/en/IssuesAndInsights/ArticlesPublications/Documents/Insu rance industry_Road ahead_FINAL.pdf

Mohan, Rakesh (2005): 'Financial Sector Reforms in India: Policies and Performance Analysis', Economic and Political Weekly, 40 (12): 1106-21.

Mohan, Rakesh (2006): "Financial Sector Reforms and Monetary Policy: The Indian Experience", Paper presented at the Conference on Economic Policy in Asia at Stanford, organized by Stanford Center for International Development and Stanford Institute for Economic Policy Research, on June 2, 2006, available at http://www.rakeshmohan.com/docs/RBIBulletinJuly2006-1.pdf

Mohan, Rakesh (2011): Growth with Financial Stability: Central Banking in an Emerging Market, Delhi: Oxford University Press. 
Mohan, Rakesh (2011a): "Development of Banking and Financial Markets in India: Restoring Growth while containing Risk", Paper 4 in Mohan (2011).

Mohan, Rakesh (2011b): "Financial Inclusion in India: A Glass Half Empty or Three Quarters Full?”, Paper 6 in Mohan (2011).

Mohan, Rakesh and Muneesh Kapur (2011): "Managing the Impossible Trinity: Volatile Capital Flows and Indian Monetary Policy", Paper 8 in Mohan (2011).

Mohan, Rakesh and Partha Ray (2011): "Development of the Indian Debt Market", Paper 5 in Mohan, (2011).

Mundra, S S (2016a): "Asset Quality Challenges in India: Diagnosis and Prognosis", Speech by RBI Deputy Governor on April 28, 2016 at the Edelweiss Credit Conclave, Mumbai, available at https://rbi.org.in/Scripts/BS_SpeechesView.aspx?Id=1001

Mundra, S S (2016b): "Asset Resolution \& Managing NPAs - What, Why and How?", Presentation of Deputy Governor, RBI at the 1st CII Banking Summit on February 11, 2016, available at https://rbidocs.rbi.org.in/rdocs/Speeches/PDFs/PPT1102166AB61D0F35C546539EF4 DCD3C83B3668.pdf

NABARD (National Bank for Agriculture and Rural Development) (2008): Report of the Committee on Financial Inclusion (Chairman: C Rangarajan), Mumbai: NABARD.

OECD (2015): Pension Markets in Focus - 2014, available at https://www.oecd.org/daf/fin/private-pensions/Pension-Markets-in-Focus-2014.pdf

Padmanabhan, G (2015): "Is India ready for full Capital Account Convertibility?", Address by Executive Director, RBI on May 16, 2015, available at https://www.rbi.org.in/Scripts/BS_SpeechesView.aspx?Id=956Reserve Bank of India (RBI) (1991): Report of the Committee on the Financial System (Chairman: M Narasimham), Mumbai: Reserve Bank of India, November.

RBI (2003): Report on Currency and Finance, 2001-02, Mumbai: RBI.

RBI (2007): Report on Currency and Finance, 2005-06, Mumbai: RBI.

RBI (2008): Report on Currency and Finance, 2006-08, Volumes 1 \& 2, Mumbai: RBI.

RBI (2009): India's Financial Sector: An Assessment, available at https://www.rbi.org.in/scripts/PublicationReportDetails.aspx?ID $=544$

RBI (2014): Report of the Committee to Review Governance of Boards of Banks in India, (Chairman: PJ Nayak), Mumbai: RBI.

RBI (2014a): Financial Stability Report, 2013-14, Issue No. 10.

RBI (2015): Report on Trend and Progress of Banking in India 2014-15, available at https://www.rbi.org.in

Shah, Ajay and Ila Patnaik (2008): "Managing capital flows: The case of India", Working Paper 2008-52, Delhi: National Institute of Public Finance and Policy.

Saraswathy M (2015): “Insurance Penetration at 10-year low”, Business Standard, June 25, 2015

Swiss Re (2015): World insurance in 2014: back to life, available at http://media.swissre.com/documents/sigma4_2015_en.pdf 
Vijay Bhaskar, P. (2014): "Non-banking Finance Companies: Game Changers", Speech by Executive Director, RBI, available at

https://www.rbi.org.in/scripts/BS_SpeechesView.aspx?Id=870

World Bank (1989): World Development Report: Financial Systems and Development, Washington DC: World Bank. 